\title{
Undergraduate Research Semester Internship Spring 1999 Abstracts and Research Papers
}

\author{
S. Dibble \\ A. Fernandez \\ C. Mayers \\ A. Omikunle \\ O. Weiss
}

May 1999

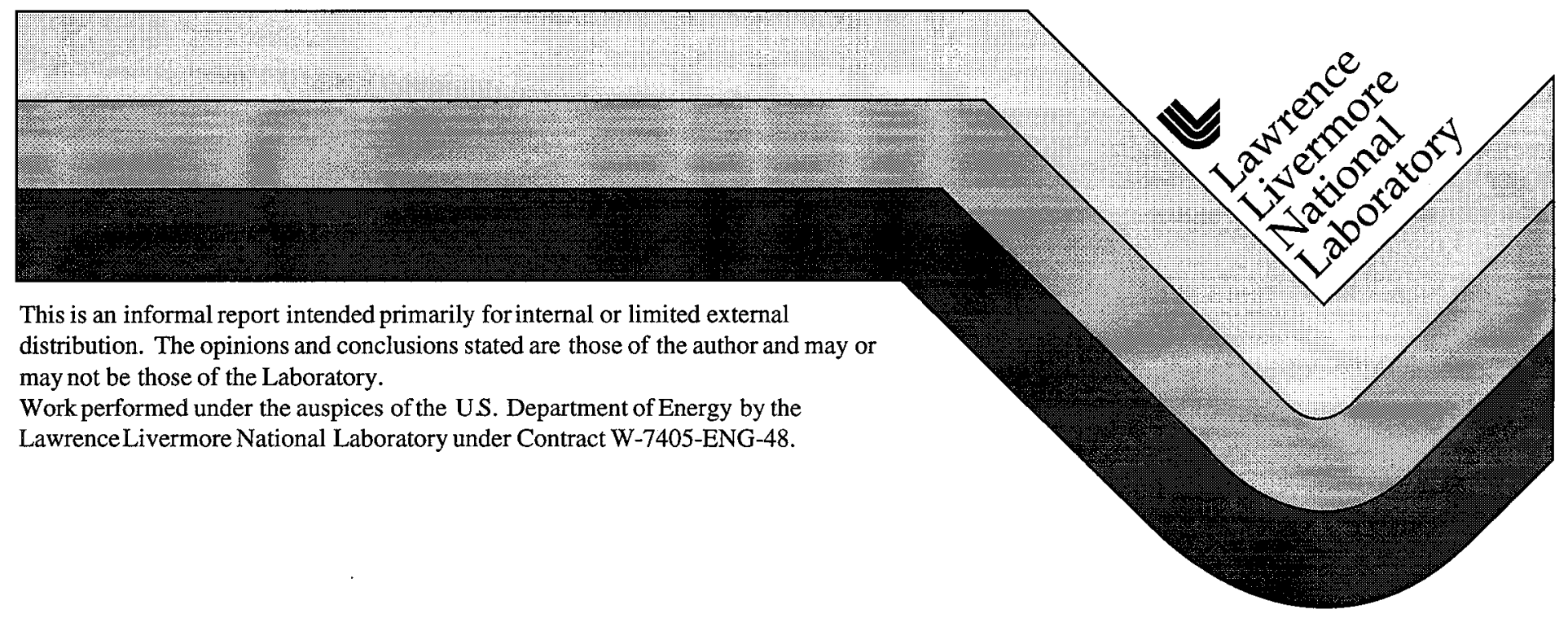




\section{DISCLAMER}

This document was prepared as an account of work sponsored by an agency of the United States Government. Neither the United States Government nor the University of California nor any of their employee, makes any warranty, express or implied, or assunes any legal liability or responsibiiity for the accuracy, completeness, or usefulness of any information, apparatus, proculc, or process disclesed or represents that its use would not iniringe privately owned rigits. Reterence herein to any geedfic commercial product, process, or service by tade name, trademark, manufachure, or othervise, does not necessarily constitute or imply its endorsement, recommendation, or favoring by the United States Covernment or the University of California. The views and opinions of authors evpressed herein do not necessarily state or reflect those of the United Siates Government or the University of Caitionia, and shall not be used for advertising or prociuct endorsement purposes.

This report has been reproduced

direcly from the best available copy.

Available to DOE and DOE contractors fom the

Office of Scientific and Tecinnical information

P.O. Box 62, Oax Ricige, IN 37831

Prices available fom (6i5) $316-8401$, FiS 626-8401

A yailable to the public from the

National Technical Information Service

U.S. Department of Commerce

5285 Port Royal Rd.

Springieid, VA 22161 


\section{Foreword}

The Undergraduate Research Semester (URS) program provides a unique and challenging off-campus research opportunity for upperdivision university undergraduate and pre-grad-school students in science, mathematics, and engineering. This internship program is a partnership between Lawrence Livermore National Laboratory, Sandia National Laboratories (New Mexico and California), and Los Alamos National Laboratory, to provide 75+ (annually) science and engineering undergraduates a rich research experience in this collaborative program.

The URS project supports the DP mission through ensuring a scientifically and technically literate citizenry, and contributes to the development of a highly skilled, diverse scientific workforce, with experience, exposure and increased awareness and support for the DP science/technology and Science Based Stockpile Stewardship. 



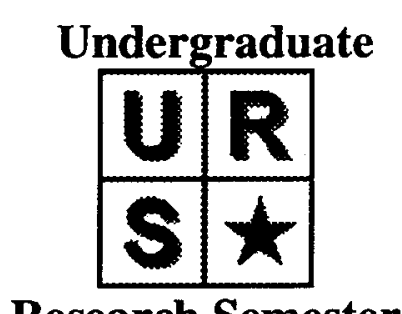

\section{Table of Contents}

\section{Abstracts:}

Stripe Dibble Development of Sieving Media for DNA Sequencing...1-11

Alfonso Fernandez Protein-Protein Interaction Specificity of a Human.... 12-26

Exonuclease

Chanda Mayers Cascading Modular Biotreatment System:

From Conceptual Design to Field Tests

Adebomi Omikunle Detecting the Unseen Enemies - Biological

Warfare

Oliver Weiss

Development of a Functional Chip for

High-Throughput Screening of

Protein-DNA Interactions 



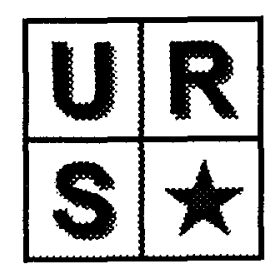

\section{Science \& Technology Education Program Spring 1999 URS Internship Program at Lawrence Livermore National Laboratory}

\section{Authors:}

- Stripe Dibble

- Alfonso Fernandez

- Chanda Mayers

- Adebomi Omikunle

- Oliver Weiss

\section{Affiliations:}

Stripe Dibble, California State University, Hayward; Alfonso Fernandez, University of Turabo; Chanda Mayers, Jackson State University; Adebomi Omikunle, Mississippi State University; Oliver Weiss, University of the Pacific 



\title{
Optimization of Sieving Media Improves Separation
}

Performance of Capillary Electrophoresis

\author{
Stripe Dibble \\ California State University, Hayward \\ Chemical Sciences Division
}

\begin{abstract}
Using polydimethylacrylamide (PDMA) as sieving media, this project evaluated the effect of increasing the PDMA's average molecular weight $\left(M_{v}\right)$ on its separation performance. Polymers of $M_{v}$ ranging from $120 \mathrm{kDa}$ to $410 \mathrm{kDa}$ were synthesized and evaluated on two components of sieving performance:

- peak-to-peak spacing (selectivity)

- peak width

As $M_{v}$ increased, selectivity also increased, but $M_{v}$ had no clear effect on peak width. These results show that increasing the $M_{v}$ of PDMA caused some improvement of sieving efficiency. To verify the observed selectivity trend and determine if a peak width trend might emerge, PDMAs of even higher $M_{v}$ should be synthesized.
\end{abstract}





\title{
Protein-Protein Interaction
}

\section{Specificity of a Human Exonuclease}

\author{
Alfonso Fernandez \\ University of Turabo \\ Biology
}

\begin{abstract}
Since little is known about the biochemical properties of Hex1/hExo1 or to which cellular pathways it contributes, we searched for and have identified several protein suspects that interact with Hex1/hExo1. To identify these interacting partners and quantify the strength of proteinprotein interactions, we employed the yeast two-hybrid system. The interactions thus far indicate a potential role for Hex1/hExo1 in mismatch DNA repair, recombination, and cell cycle control.

To better understand the biochemical properties of Hex1/hExol1, we have expressed two functional domains of the protein, the $\mathrm{N}$-terminal and $\mathrm{C}$-terminal regions. The $\mathrm{N}$-terminal region exhibits a powerful nuclease function. We are currently designing C-terminal expression constructs that might be involved in determined interacting specificity with other proteins. Solubility of the C-terminal domain will be monitored by Western blotting techniques after His-tagging the protein. Applying crude cell extract to a nickel affinity column will allow for purification of this fragment. Both domains (N-terminal and $\mathrm{C}$-terminal) will be used for further biochemical and protein interaction studies.
\end{abstract}





\title{
Cascading Modular Biotreatment System: From Conceptual Design to Field Tests
}

\author{
Chanda L. Mayers \\ Jackson State University \\ B.S. Biology, December 1998
}

\begin{abstract}
Elevated nitrate concentrations in ground water at Lawrence Livermore National Laboratory's (LLNL) Site 300 may pose toxicological and ecological effects. This study evaluates the efficiency of phytoremediation in a constructed wetland to remove nitrate from ground water. A cascading modular biotreatment system (CMBS) was designed and is currently undergoing testing at the Livermore site. Phytoremediation proved effective in removing nitrate from ground water. Since the rate of nitrate removal is influenced by climate and growth media. Optimal operational criteria are still under evaluation.
\end{abstract}





\title{
Detection and Identification of Biological Warefare Agents
}

\author{
Adebomi Omikunle \\ Mississippi State University \\ B.S. Microbiology, December 1998
}

\begin{abstract}
The overall goal of this project is to use mass spectrometry to develop rapid, real-time, and facile methods for remote detection of biological warfare agents in the atmosphere. To facilitate these aims, studies were conducted using simulants of Bacillus anthracis (our model organism and the causative agent of anthrax). The major spore coat proteins of the simulants were isolated and characterized and then analyzed by mass spectrometry. Results should provide unique molecular signatures enabling the identification of similar biological warfare agents in sample aerosol.
\end{abstract}





\title{
Development of a Functional Chip for High-Throughput
}

\section{Screening of Protein-DNA Interactions}

\author{
Oliver Weiss \\ University of the Pacific \\ Biology
}

\begin{abstract}
An oligonucleotide "functional chip" containing a variety of structurally different DNA fragments chemically linked to a glass surface is under development for analysis of protein-DNA binding interactions. The functional chip ultimately will be used to screen proteins for their ability to bind a wide range of DNA including single-stranded, double-stranded, and structurallymodified DNA fragments. Of special interest are novel DNA repair proteins which will be tested for their DNA binding capacity against these different DNA substrates. The prototype functional chip was generated by the application of DNA chemically cross-linked onto a glass slide in a microarray format. DNA spotted in this manner allows for analysis of proteins against different DNA samples on a single slide. The proteins to be investigated are applied individually to the chip and the protein-DNA interaction chemically stabilized. The protein-DNA interaction is visualized using fluorescent immunocytochemical techniques for detection of the protein-DNA binding events. To date, we have examined the protein-DNA interactions of RecA, a DNA-dependent ATPase. This work was performed under the auspices of the U.S. DOE by LLNL under contract no. W-7405-ENG-48.
\end{abstract}





\title{
OPTIMIZATION OF SIEVING MEDIA IMPROVES SEPARATION PERFORMANCE OF CAPILLARY ELECTROPHORESIS
}

\author{
Stripe Dibble \\ California State University, Hayward \\ Lawrence Livermore National Laboratory \\ Livermore, California 94551
}

May 27, 1999

Prepared in partial fulfillment of the requirements of the Undergraduate Research Semester under the direction of Ramakrishna Madabhushi, Research Mentor, in the Lawrence Livermore National Laboratory.

* This research was supported in part by an appointment to the U.S. Department of Energy, Office of Defense Programs, Undergraduate Research Semester (hereinafter called URS) program administered by University of California, LLNL under contract W-7405Eng-48 with Lawrence Livermore National Laboratory.

By acceptance of this article, the publisher or recipient acknowledges the U.S. Government's right to retain a non-exclusive, royalty-free license in and to any copyright covering this article. 


\title{
OPTIMIZATION OF SIEVING MEDIA IMPROVES SEPARATION PERFORMANCE OF CAPILLARY ELECTROPHORESIS
}

\author{
Stripe Dibble \\ California State University, Hayward \\ Chemical Sciences Division
}

Using polydimethylacrylamide (PDMA) as sieving media, this project evaluated the effect of increasing the PDMA's average molecular weight $\left(M_{v}\right)$ on its separation performance. Polymers of $M_{v}$ ranging from $120 \mathrm{kDa}$ to $410 \mathrm{kDa}$ were synthesized and evaluated on two components of sieving performance:

- peak-to-peak spacing (selectivity)

- peak width

As $M_{v}$ increased, selectivity also increased, but $M_{v}$ had no clear effect on peak width. These results show that increasing the $M_{v}$ of PDMA caused some improvement of sieving efficiency. To verify the observed selectivity trend and determine if a peak width trend might emerge, PDMAs of even higher $M_{v}$ should be synthesized.

5/27/99 Rev. 1 


\section{Introduction}

The goal of this project was to improve separation performance of Capillary electrophoresis (CE). Previous research indicated that using polydimethylacrylamide (PDMA) of high molecular weight as sieving media should result in improved separation performance.

Specifically, I wished to investigate the effect of varying PDMA's molecular weight on the following components of separation performance:

- full width at half maximum (FWHM)

- peak to peak distance (selectivity)

\section{Methods Used}

\section{Polymer Synthesis:}

- Purified monomer polymerized using predetermined amounts of Ammonium Persulfate (APS) as the initiator and Tetramethylethylenediamine (TEMED) as the catalyst

- Keeping temperature between 3-7oC during polymerization critical to prevent early chain termination

- Different molecular weights achieved by changing amount of monomer in polymerization mixture

- Ar gas bubbled through reaction flask for 15 minutes

- Polymers refrigerated for 12 hours to ensure complete reaction

- Polymers freeze-dried to remove excess water

\section{Assessment of average molecular weight $\left(M_{v}\right)$}

- Intrinsic viscosity [ $\eta]$ determined by viscosity measurements taken with Ubbelohde viscometer

- $M_{v}$ was then calculated using the Mark-Houwink equation [1]:

$$
[\eta]=k \mathrm{M}_{\mathrm{v}}{ }^{\mathrm{a}}
$$

where $k=23.2 \times 10^{-3} \mathrm{~mL} / \mathrm{g}$ and $\mathrm{a}=0.81$ in water at $25^{\circ} \mathrm{C}$ 
Preparing polymers for use as sieving media

- 0.3 g PDMA

- 3.6 g $6 \mathrm{M}$ urea

- $1 \mathrm{~mL}$ 10X TAPS buffer

- $6.4 \mathrm{~mL} \mathrm{d \textrm {d } _ { 2 } \mathrm { O }}$

- dissolve urea in water, add buffer, then polymer, dissolve overnight

\section{Sample preparation}

- BigDye ${ }^{\mathrm{TM}}$ Terminator Cycle Sequencing Standard with AmpiTaqFS

- add $40 \mathrm{uL} \mathrm{dH}_{2} 0$

- denature for 4 minutes at $90^{\circ} \mathrm{C}$

- use $10 \mathrm{uL}$ for sample, keep remainder in freezer

\section{Electrophoresis}

- instrument: Perkin-Elmer ABI Prism ${ }^{\mathrm{TM}} 310$ Genetic Analyzer

- uncoated silica capillaries

- 50 um inside diameter

- 360 um outside diameter

- total length: $51 \mathrm{~cm}$

- injection inlet to detection zone: $40 \mathrm{~cm}$

- field strength for electrokinetic loading: $60 \mathrm{~V} / \mathrm{cm}$ for 4 seconds

- separation performed at $160 \mathrm{~V} / \mathrm{cm}$

- temperature: $40^{\circ} \mathrm{C}$ 


\section{Data}

\begin{tabular}{|ccccc|}
\hline$\underline{M}_{\underline{v}}(\mathrm{kDa})$ & ${\underline{\eta_{s p}}}_{\text {(dL/g) }}$ & $\begin{array}{c}\text { xover } \\
\text { (base\#) }\end{array}$ & $\frac{\text { B-field visc. }}{(\mathrm{cP})}$ \\
119 & 2.99 & 363 & $<170$ \\
205 & 4.66 & 469 & 4200 \\
421 & 8.34 & 520 & high \\
\hline
\end{tabular}

\section{Discussion}

Figures 1 and 2 show a comparison of three different PDMAs for peak width and peak-to-peak separation. Peak separation shows a clear trend and the data points fall in a relatively smooth line. It is harder to make such a definitive statement about the FWHM data.

In order to quantitiatively analyze the resolution of the $A B I$ sequencing runs, peak spacing per base $(\mathrm{mm})$, and average full width at half-maximum were plotted on a graph as a function of the DNA fragment (base) number $(N)$ (Figs $3 \& 4$ ). The point at which the two plots intersect is the point at which the FWHM equals peak spacing per base and the corresponding $\mathrm{N}$ value is the approximate number of resolvable DNA fragments, or the length of read (LOR), with a resolution value of 0.59 . The resolution, $R$, follows the equation $[2,3]$ :

$\left.\mathrm{R}=[2 \ln 2)^{1 / 2} \Delta \mathrm{t}_{\mathrm{m}}\right] /\left(h \mathrm{w}_{1}+h \mathrm{w}_{2}\right) \Delta \mathrm{B}$

Where $\Delta \mathrm{tm}$ is the difference in migration time between the two adjacent peaks, $h w_{1}$ and $h w_{2}$ are the peak full width at halfmaximum (in time units), and $\Delta B$ is the difference in base number between the two fragments. 
Fig. 1 Peak Width (FWHM)

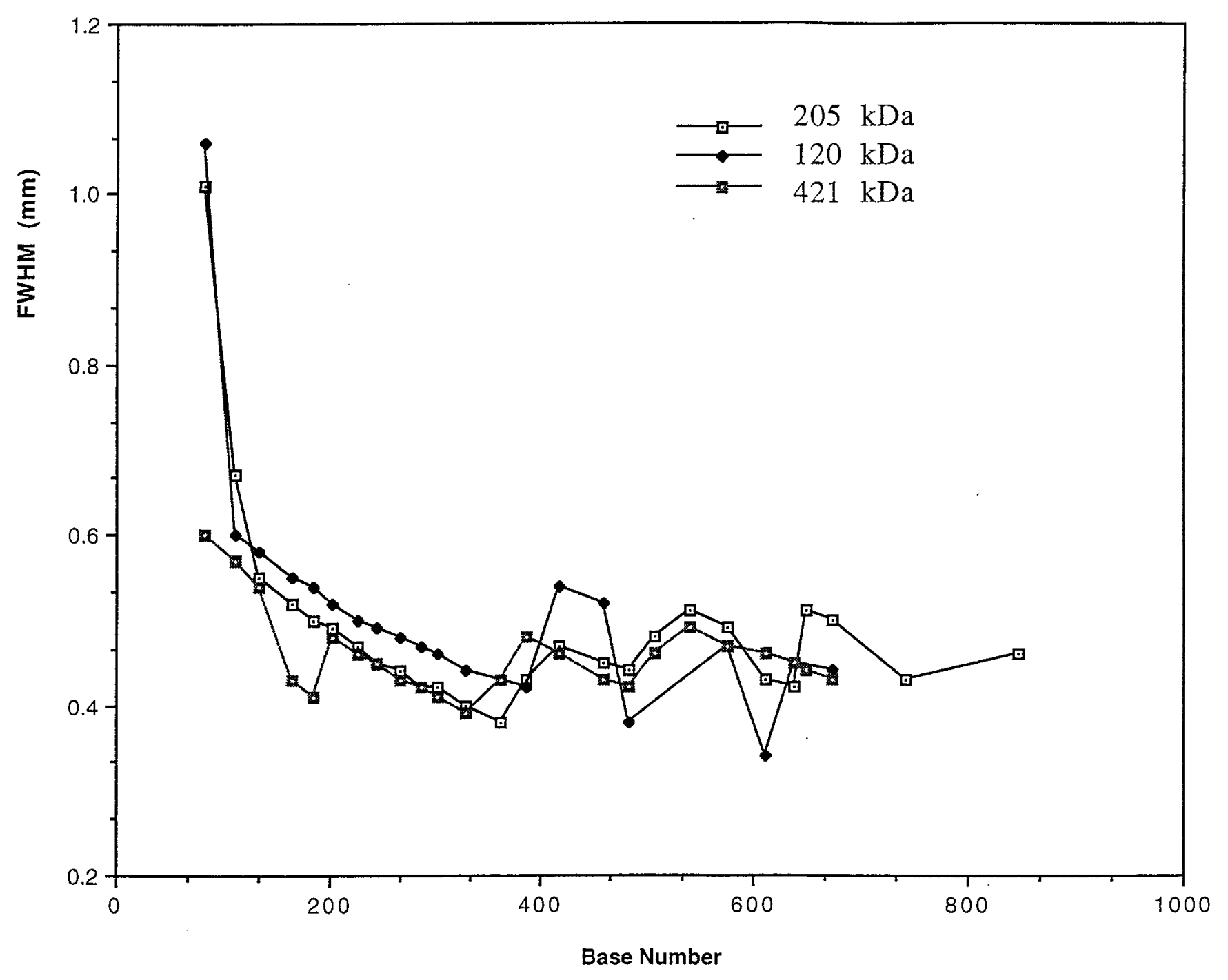


Fig. 2 Selectivity

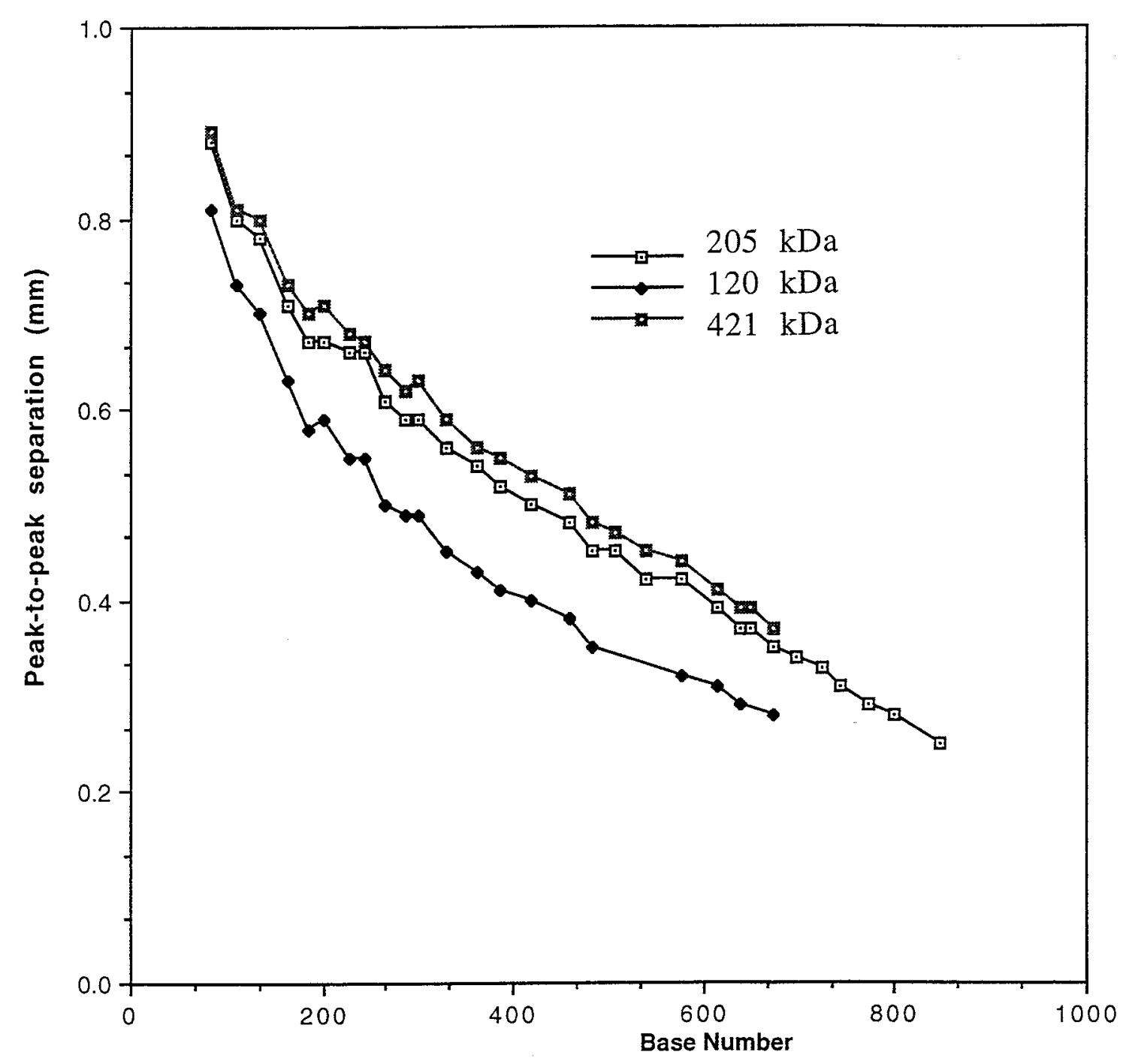




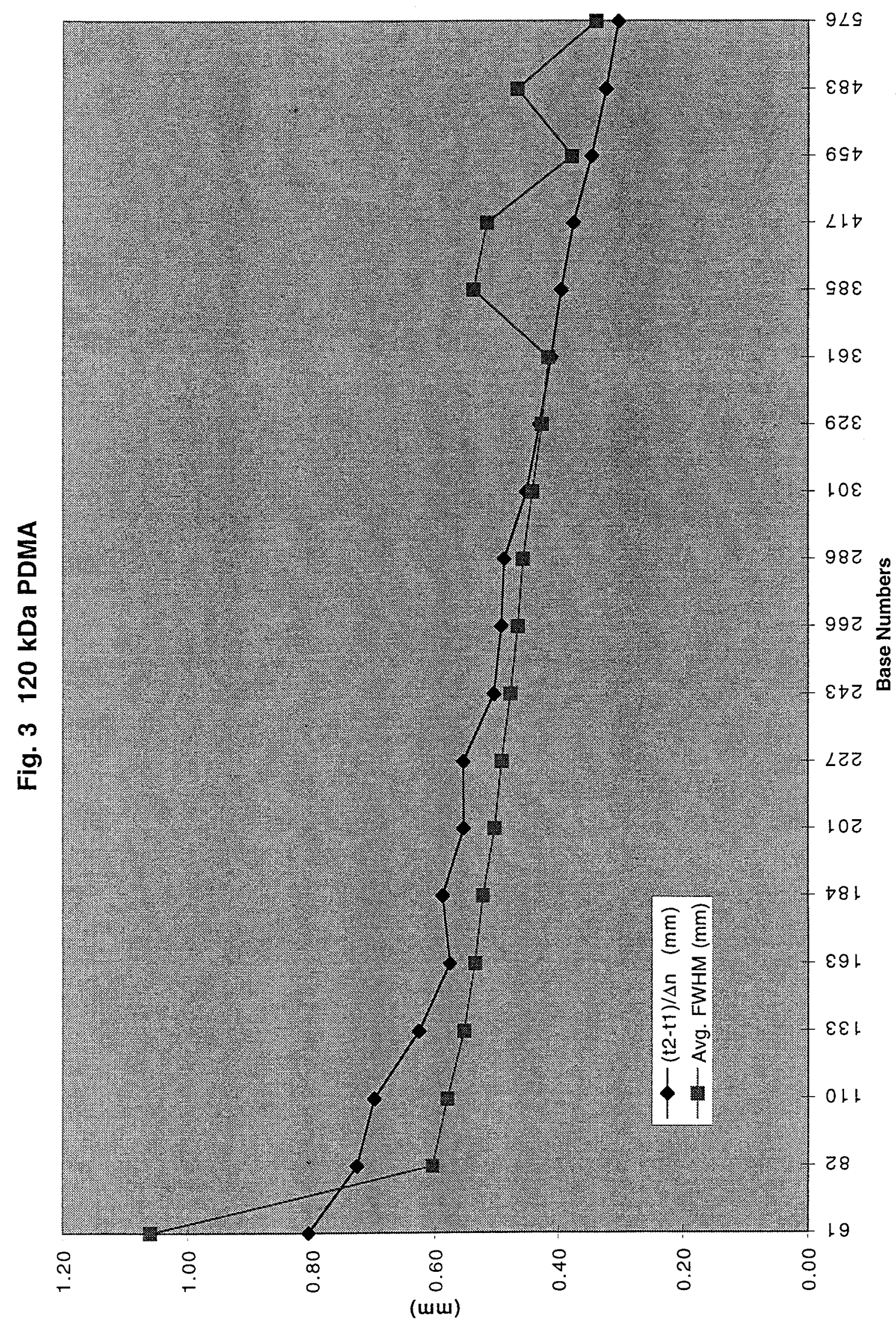




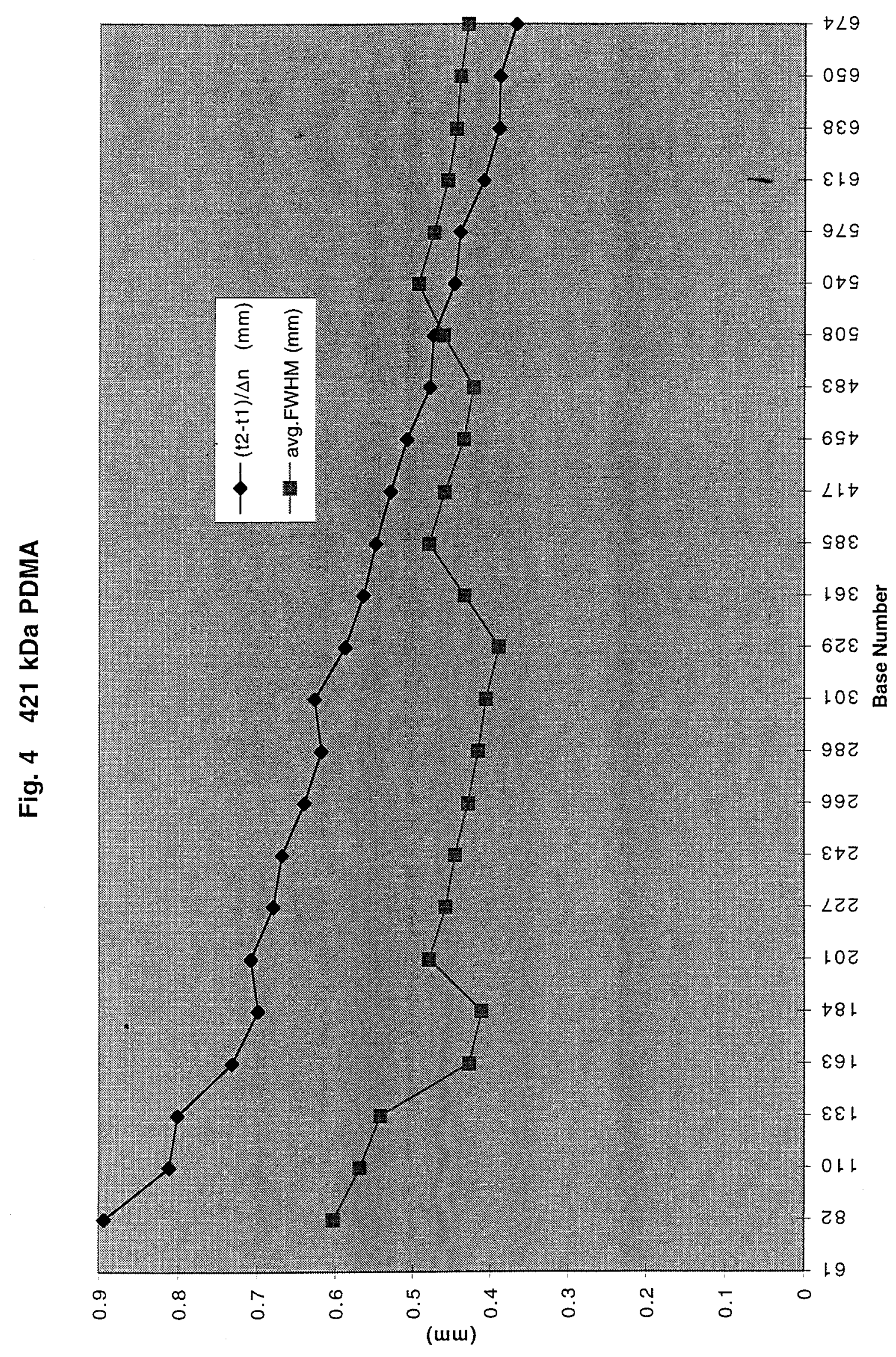




\section{Analysis of Results}

The results show an increase in separation performance in relation to increasing $\mathrm{M}_{\mathrm{v}}$. The improvement in selectivity is clear, but the peak width trend is not so clear. Optimally, a polymer would have a low FWHM (sharp, narrow peaks), and high peak-to-peak spacing.

\section{Su m mary}

While the polymers created thus far show promise in terms of somewhat lower peak width and greater peak separation values, a greater spectrum of molecular weights would provide an even clearer picture of the effect of higher $\mathrm{Mv}$ on separation performance. The current synthesis method appears to be effective for creating polymers of up to $421 \mathrm{kDa}$, but not much higher. In the next phase of this research, other synthesis methods (such as lowering initiator concentration will be tried in order to achieve PDMA polymers of even higher molecular weights. 


\section{Bibliography}

Brandrup, J., Immergut, E.H., in: Polymer Handbook, Wiley, New York 1989.

Madabhushi, R., Vainer, M., dolnik, V., Enad, S., Barker, D.L., Harris, D.H., Mansfield, E.S., "Versatile low-viscosity sieving matrices for nondenaturing DNA separations using capillary array electrophoresis, Electrophoresis 1997, 18, 104-111.

Madabhushi, R., "Separation of 4-color DNA sequencing extension products in noncovalently coated capillaries using low viscosity polymer solutions", Electrophoresis, 1998, 19, 224-230. 


\title{
Protein-Protein Interaction Specificity of a Human Exonuclease
}

\author{
Alfonso Fernandez, University of Turabo, Gurabo, PR \\ Biology and Biotechnology Research Program, David Wilson III, and Byung-In Lee \\ Lawrence Livermore National Laboratory \\ Office of Defense Programs, U.S. Dept. of Energy
}

\begin{abstract}
Since little is known about the biochemical properties of Hex1/ hExo1 or to which cellular pathways it contributes, we searched for and have identified several protein suspects that interact with Hex $1 /$ hExo1. To identify these interacting partners and quantify the strength of protein-protein interactions, we employed the yeast two-hybrid system. The interactions thus far indicate a potential role for Hex $1 / \mathrm{hExol}$ in mismatch DNA repair, recombination, and cell cycle control.

To better understand the biochemical properties of Hex $1 / \mathrm{hEx}$ 1, we have expressed two functional domains of the protein, the $\mathrm{N}$-terminal and $\mathrm{C}$-terminal regions. The $\mathrm{N}$-terminal region exhibits a powerful nuclease function. We are currently designing C-terminal expression constructs that might be involved in determined interacting specificity with other proteins. Solubility of the C-terminal domain will be monitored by Western blotting techniques after His-tagging the protein. Applying crude cell extract to a nickel affinity column will allow for purification of this fragment. Both domains ( $\mathrm{N}$-terminal and $\mathrm{C}$-terminal) will be used for further biochemical and protein interaction studies.
\end{abstract}

\section{INTRODUCTION}

DNA is susceptible to a great number of alterations that can be fatal or lead to permanent genetic changes. Metabolic derived compounds (e.q. reactive oxygen species) as well as chemical and physical environmental agents (e.g. ultraviolet light, X-rays, and food mutagens) are a major cause of DNA damage. Our project involves characterizing specific protein-protein interactions that take place during DNA mismatch repair, replication, and 
recombination. These three processes are crucial for maintaining the integrity of DNA.

We are working with two similar human proteins known as Human Exonuclease $1(\mathrm{Hex} 1 / \mathrm{hExo} 1)$ that differ only in their Cterminal content; the latter protein maintains an extension of 43 amino acids. The same gene, located at chromosomal position of 1q42-43, encodes both human proteins. In some cases this region is lost in cells suffering from leukemia and other solid tumors. Hex1 protein is the product of an alternatively spliced transcript that introduces a premature stop codon, while hExo1 is the larger 846 amino acid protein.

Hex1/hExo1 contains significant homology with yeast exonuclease 1 and other members of the RAD2 nuclease family. All these proteins contain $\mathrm{N}$-terminal and internal regions comprising the conserved nuclease domain, and exhibit $5^{\prime}$ nuclease activity. The nuclease activity of Hex1/hExo1 likely operates during mismatch repair and homologous recombination. Mismatched base pairs arise via mispairing of nitrogen bases during DNA replication. If this mismatch is not repaired properly, these errors will accumulate in DNA, promoting the formation of cancer and human disease, such as Hereditary Nonpolyposis Colorectal Cancer (HNCC).

Homologous recombination is a normal process during meiosis, in which pairs of essentially identical chromosomes exchange short sequences of DNA. This is crucial for evolutionary processes due to the need for genetic variability in a population. Also, recombination is an important process for the repair of DNA double stand breaks, which are considered one of the most dangerous types of damage in cells due to the lack of a correct template.

The precise biochemical role of Hex $1 / \mathrm{hExo} 1$ remains undefined. Expression studies suggest that these proteins are involved in processes during hemopoetic stem cell development, such as $V(D) J$ recombination and isotype switching of antibodies, and in meiotic recombination. Our studies involve the confirmation of the protein-protein interaction partners of Hex 1 that have been identified (Figure 1). We employed the yeast two-hybrid system to 
confirm all interactions. This technique will also be used for hExo1, using the same interacting partners of Hex1, to find out if the C-terminal extension affects the specificity of the protein. Once all the interactions are confirmed, we are going to map the interacting domains responsible for the physical association. Since the biochemical role of Hex $1 / \mathrm{hExo} 1$ is not well defined, these studies will provide a better picture of the biochemical pathways of DNA replication, mismatch repair, and homologous recombination.

\section{MATERIALS}

\section{Construct of Two-Hybrid Vectors}

PCR primers were used to introduce BamH1 and Nco1 restriction sites into Hex $1 / \mathrm{hEx} 1 \mathrm{cDNA}$. PCR products were purified and digested, such that cloning into the BamH1 site of the twohybrid vector will form an in-frame fusion to the vector encoded Gal4 domain. Hex1/hExo1 were subcloned separately into pAS2-1 vector for the yeast two-hybrid system. Potential protein partners of Hex1/hExo1 were subcloned pACT2 vector.

\section{Colony Lifting Assay and Histidine Selection Media}

We used the yeast cell line, PG69, for the transformation of the two-hybrid vector in a Synthetic Dropout (SD) solid media lacking of tryptophan (trp) and leucine (leu). After 4-6 days the colonies were transfered into a SD/-Trp/-Leu/-Histidine (his) solid media. To get a qualitative result of the protein-protein interactions, we employed the colony-lifting assay using $\mathrm{x}$-gal as a substrate. Colonies that turned blue indicated an interaction is occurring.

A solid media of $\mathrm{SD} /$-His, was used as another reporter gene for the protein-protein interaction. Only the colonies that grow in that media are the ones where the protein-protein interaction is taking place, since they need to produce histidine in order to grow in the selection media. Histidine production results from the activation of the Gal4 promotor region, which is dependent upon a strong protein-protein interaction. 


\section{Strength of Interaction}

To determine the strength of interaction between Hex 1 and a candidate complex partner, yeast cells were inoculated into liquid culture of SD/-Leu/-Trp/-His . The activity of $\beta$-galactosidase was determined by using a liquid culture that contains o-nitrophenil $\beta$-D-galactopyranoside (ONPG) as a substrate. ONPG is ten millions times less sensitive than $\mathrm{x}$-gal. The strength of interaction is based on the gal-units which is calculated from a formula where the variables, such as time of color development and OD readings, are values taken from the experiment. The higher the value of the gal-units, the stronger the interaction.

\section{Truncations and Protein Expression of Hex1/hExo1}

Truncations of Hex $1 / \mathrm{hExo} 1$ were made by PCR, using primers that contain BamH1 or Nco1 restriction sites. Amino terminal deletions were introduced to obtain stable polypeptides composed of the C-terminal domains that likely direct protein-protein interactions. Each C-terminal domain was cloned into pET11d and transformed into $\mathrm{DH} 5 \propto$ competent cells. After confirming the recombinant construct by electrophoresis on a $1 \%$ agarose gel of the digested minipreps. The positive clones were then transformed intoBL21 competent cells. Colonies were resuspended in $3 \mathrm{ml}$ LB/ampicilin $(50 \mu \mathrm{g} / \mathrm{ml})$, where $200 \mu \mathrm{l}$ of cell resuspension was used to inoculate $2 \mathrm{ml} \mathrm{LB} /$ ampicillin $(50 \mu \mathrm{g} / \mathrm{ml})$ for a $2 \mathrm{hr}$ incubation to obtain an OD reading of 0.5 to 0.65 . After getting the desired OD, the cells were induced for $3 \mathrm{hr}$ using isopropyl- $\beta-D$-thiogalactosidase (IPTG) at a final concentration of $0.5 \mathrm{mM}$. Cells were harvested by centrifugation at $12,000 \mathrm{rpm}$ for $30 \mathrm{~min}$ at $4{ }^{\circ} \mathrm{C}$. The bacterial pellet was resuspended with $500 \mu \mathrm{l}$ cold sonication buffer $(10 \mathrm{mM}$ Hepes, $100 \mathrm{mM} \mathrm{KCl}, 2 \%$ glycerol). Cells were lysed by $10 \mathrm{sec}$ of sonication, with $1 \mathrm{sec}$ of resting period for every $3 \mathrm{sec}$. Supernatant was separated from the pellet by centrifugation at $14,000 \mathrm{rpm}$ for $5 \mathrm{~min}$ at $4{ }^{\circ} \mathrm{C}$. The pellet was resuspended with $500 \mu \mathrm{l}$ of $5 \mathrm{M}$ urea. Both, supernatant and resuspended pellet were analyzed on an SDS-PAGE. Proteins were stained with a coomassie blue solution. 


\section{RESULTS}

\section{Confirmation of Hex1 Protein-Protein Interaction Suspects}

All the yeast colonies, except the ones containing pASHex1/pACT-Rad50 constructs, were able to grow in the SD/-His selection media due to the activation of the Gal4 promotor region as a result of a protein-protein interaction. When performing the $\beta$-galactosidase, yeast colony-lift assay, pAS-Hex1/pACT-Rad50 was also negative. In addition, Hex1 interactions with an SNF2-like protein, autoantigen, and a pre B cell factor, gave negative results. The rest of the constructs were positive in the $\beta$-galactosidase assay, since the colonies were able to turn blue after applying $x$-gal substrate. These results describe possible protein-protein interactions with Hex1.

\section{Strength of Interaction}

The minimal $\mathrm{x}$-gal values ranged for 2 to 0.5 . In this range, Hex 1 protein interactor suspects were autoantigene, pre $B$ cell, and SNF2 like protein. The proteins 14-3-3 and hMsh2 were identified in the range of 12 to 15 . The highest activity was obtained with interactions of Hex1 full length (803 amino acids) with hMre11, and with a truncated version of Hex 1 (a C-terminal polypeptide of 411 amino acids) and hMre11. The interaction of Hex1-Hex1 gave approximately $5 \mathrm{x}$-gal units.

\section{DISCUSSION}

\section{Protein-Protein Interactions}

The fact that the yeast constructs Hex1-Rad50 were negative for the two reporter genes, $\mathrm{SD} /$-His selection media and $\beta$ galactosidase activity, suggests that there is no interaction between these two proteins (Table 1). Interestingly hMre11, a protein that works as a complex with $\operatorname{Rad50,}$ was positive for both reporter genes when exposed to Hex 1 in the yeast two-hybrid assay. Moreover, the strength of this interaction, determined in the liquid culture assay 
(using ONPG as a substrate), was the strongest among the Hex1 interactor suspects (Figure 2).

The complex of Rad50, hMre11, and a protein named XRS2, is required for DNA end processing during double strand break as well as for the introduction of DNA double strand breaks during meiotic recombination. It is known that Rad50 interacts physically with DNA strands, and hMre11 with Rad50 and XRS2. Further studies need to be done to find out if Hex1 interacts with XRS2. This finding will provide a better picture of the spatial arrangement of hMre11-Rad50-XRS2 complex and how Hex1 communicates during recombination. Additional studies along these lines will help define, the biochemical pathway of homologous recombination.

In relation with SNF2 like protein, autoantigen, an pre B cell, they were all positive on $\mathrm{SD} /$-His selection media and negative in the $\beta$-galactosidase activity (Figure 1 ). Since $\mathrm{SD} /$-His is a more powerful reporter gene, our results suggest that these are weak interactions. When the strength of interaction was determined (refer to figure 2), our findings were consistent with this prediciton. The significance of these weak interactions is presently unknown. To determine how weak they are, we will need to employ a positive control of known interaction strength for comparative analysis.

\section{Hex1 Self Interaction}

Hex1-Hex1 was positive on the $\mathrm{SD} /$-His selection media and in the $\beta$-galactosidase activity. The strength of interaction was less strong, than Hex1-hMre11. Again, we need a known positive control for comparison to determine stability of the Hex1 self-association.

\section{Specificity Region of Hex1}

Past experiments proved that the nuclease activity of Hex $1 / \mathrm{hExo} 1$ is located at the $\mathrm{N}$-terminal and internal regions of the protein. These two areas contain significant homology to the $\operatorname{Rad} 2$ family. The region responsible for the specificity of Hex 1 is proposed to be located at the C-terminal end due to its lack of homology to any other protein. In order to confirm this hypothesis, a polypeptide composed of Hex 1 C-terminal region of 411 amino 
acids was used to examine for an interaction with hMrell full length (FL) in the yeast two-hybrid system. The strength of interaction was similar to that observed for hMre11 FL/Hex 1 FL. The results indicate that the C-terminal polypeptide was responsible for the Hex 1 specificity. To strengthen our hypothesis, interaction studies need to be done using the rest of our protein candidates.

\section{Solubility of $\operatorname{Hex1/hExo1}$}

Hex $1 / \mathrm{hExo} 1$ are susceptible to self-degradation in vivo. Stable polypeptides were created to carry out biochemical studies of both proteins. To study the solubility of the C-terminal domains of both proteins, induced cells for protein expression were lysed by sonication and the supernatant was separated from the pellet. Soluble proteins are located in the supernatant and insoluble protein in the pellet. These samples were used to run a $10 \%$ SDSPAG. After staining the protein gel, we found that the soluble and insoluble fractions were similar in both cases for Hex and hExol (Figure 3). The results indicate that the C-terminal polypeptides are partially insoluble.

\section{CONCLUSION}

According to the yeast two hybrid system, Rad50 was the only candidate that did not interact with Hex1. Our findings indicate

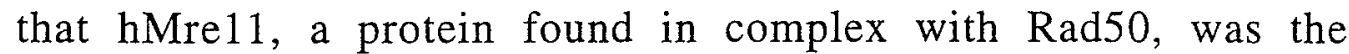
strongest interaction. Hex1 was also shown to interact with itself. Further studies need to be done to understand the biological role of these interactions.

The C-terminal region of Hex 1 is likely to be involved in determining the interaction specificity with other proteins. Even though the chemical structure of Hex $1 / \mathrm{hExo} 1$ remains undefined, we know that the C-terminal region is partially insoluble. This is a very important approach to understand the biochemical characteristic of these interactions.

Finally, the protein-protein interaction suspects of hExo1 will be tested. We wish to determine if the C-terminal differences 
between hExol (which maintains an additional 43 amino acids) and Hex1 affect the protein-protein interaction specificity of these human nucleases. All the interactions identified in the yeast twohybrid system will be confirmed by applying human cell crude extracts to a affinity column containing full length or truncated Hex1/hExo1 protein. This technique might also reveal additional protein partners. Both human proteins have already been histagged by subcloning into pET28 vector. Presently, studies are ongoing to confirm the expression of the tagged protein using western blot techniques.

\section{SUMMARY}

It is very important to understand how Hex $1 / \mathrm{hExol}$ contributes to DNA repair, which is considered one of the most important processes in cells. Most of the biochemical pathways in DNA repair involve protein-protein interactions and protein-DNA interactions. An organism lacking at least one of the proteins that play a crucial role in DNA repair is likely to develop fatal diseases, such as cancer. Our contribution is to define the biological role and pathways to which Hex1/hExo1 contribute (Figures 4 and 5).

We were able to create a list of protein candidates that likely interact with Hex1. Some of these interactions are already confirmed by employing several biochemical approaches. In addition some of the biochemical characteristics of Hex1, such as the solubility of the C-terminal interacting region are under study. Our project will help to define a subset of molecular interactions that play a crucial role in DNA repair, replication, and recombination. 


\section{REFERENCES}

1. Chien, C.T.,, Bartel, P.L., Rolf, S., and Stanley, F., The two-hybrid system: A method to identify and clone genes for proteins that interact with a protein of interest, Pro. Natl. Acad. Sci. USA, Vol. 88, Biochemistry (November 1991), pp. 9578-9582

2. Fields, S., and Rolf, S., The two-hybrid system: an assay for protein-protein interactions, TIG Vol.10, No. 8 (August 1994), pp. 286-291.

3. Shinohara, A., and Ogawa,T., Homologous recombination and the roles of double-strand breaks, TIB 2 (October 1995), pp. 387-391

4. Tishkoff, D.X., Boerger, A.L., Bertrand, P., Filosi, N., Gaida, G.M., Kane, M.F., and Kolodner, R.D., Idendification and characterization of Saccharomyces cerevisiae EXO1, a gene encoding an exonuclease that interacts with MSH2, Proc. Natl. Acad. Sci. USA, Vol. 94, Genetics (July 1997), pp. 7487-7492

5. Wilson III, D.M., and Thompson L.H., Life without DNA repair, Proc. Natl. Acad. Sci. USA, Vol. 94 (November 1997), pp. 1275712754

6. Wilson III, D.M, Carney, J.P., Coleman, M.A., Adamson, A.W., Christensen, M., and Lamerdin, J.E., HexI: a new human Rad2 nuclease family member with homology to yeast exonuclease 1 , Nucleic Acids Research, Vol. 26 No. 16 (1998), pp. 3762-3768 


\section{APPENDIXES}

A

- 14-3-3: a cell cycle protein that regulates mitosis, preventing the cell from replicating until DNA damage is repaired.

- SNF2 like protein: chromatin-remodeling factors that potentially exhibit helicase activity.

- Autoantigen: protein found in human testis.

- Human pre B cell enhancing factor: transcriptional regulator specific for lymphoid tissues.

B

- hMsh2: homologous to the E.coli MutS protein which plays a crucial role in mismatch damage recognition and repair.

Mutation of hMsh2 influences the development of Hereditary Non-Polyposis Colorectal Cancer (HNPCC).

- hMre11: a $3^{\prime}$ to 5' exonuclease that is involved in DNA end processingat double strand breaks (DSB) during repair and meiotic recombination.

- Rad50: Mre11 and Rad50 act in a complex during DBB repair and meiotic recombination.

Figure 1A. Hex1 interaction suspects that were previously identified in the yeast two-hybrid system. Using these clones the strength of interactions with the Hex 1 were determined. Figure 1B. The following proteins were additional Hex 1 protein interaction suspects that need to be confirmed in the yeast twohybrid system. Due to their specific role of these proteins in DNA repair, they were predicted thought to interact with Hex 1 . 


\section{TABLE 1}

\section{Interactions with Hex1-Binding Domain (BD)}

\begin{tabular}{|c|c|c|}
\hline Activation Domain & $\begin{array}{c}\text { SD/-His Selection } \\
\text { Media }\end{array}$ & $\begin{array}{c}\beta \text {-galactosidase } \\
\text { activity }\end{array}$ \\
\hline Hex1 & + & + \\
\hline HMre11 & + & + \\
\hline HMsh2 & + & + \\
\hline Rad50 & - & - \\
\hline 14-3-3 & + & + \\
\hline SNF2 like protein & + & - \\
\hline Autoantigen & + & - \\
\hline Pre B cell & + & - \\
\hline
\end{tabular}

Each protein candidate was subcloned into pACT 2 vector, which contains Gal4 activation domain. In $\mathrm{SD} /$-His selection media, the positive results correspond to the yeast constructs that were able to grow in the media, suggesting protein-protein interaction. In relation to the $\beta$-galactosidase activity, the positive results refer to the development of the blue color in yeast colonies when applying $\mathrm{x}$-gal substrate. Blue colonies also suggest protein-protein interaction.

*hExo1-BD protein interactors will be screened in $\mathrm{SD} /$-His selection media next time as well as their $\beta$-galactosidase activity. 


\section{Strength of Interaction}

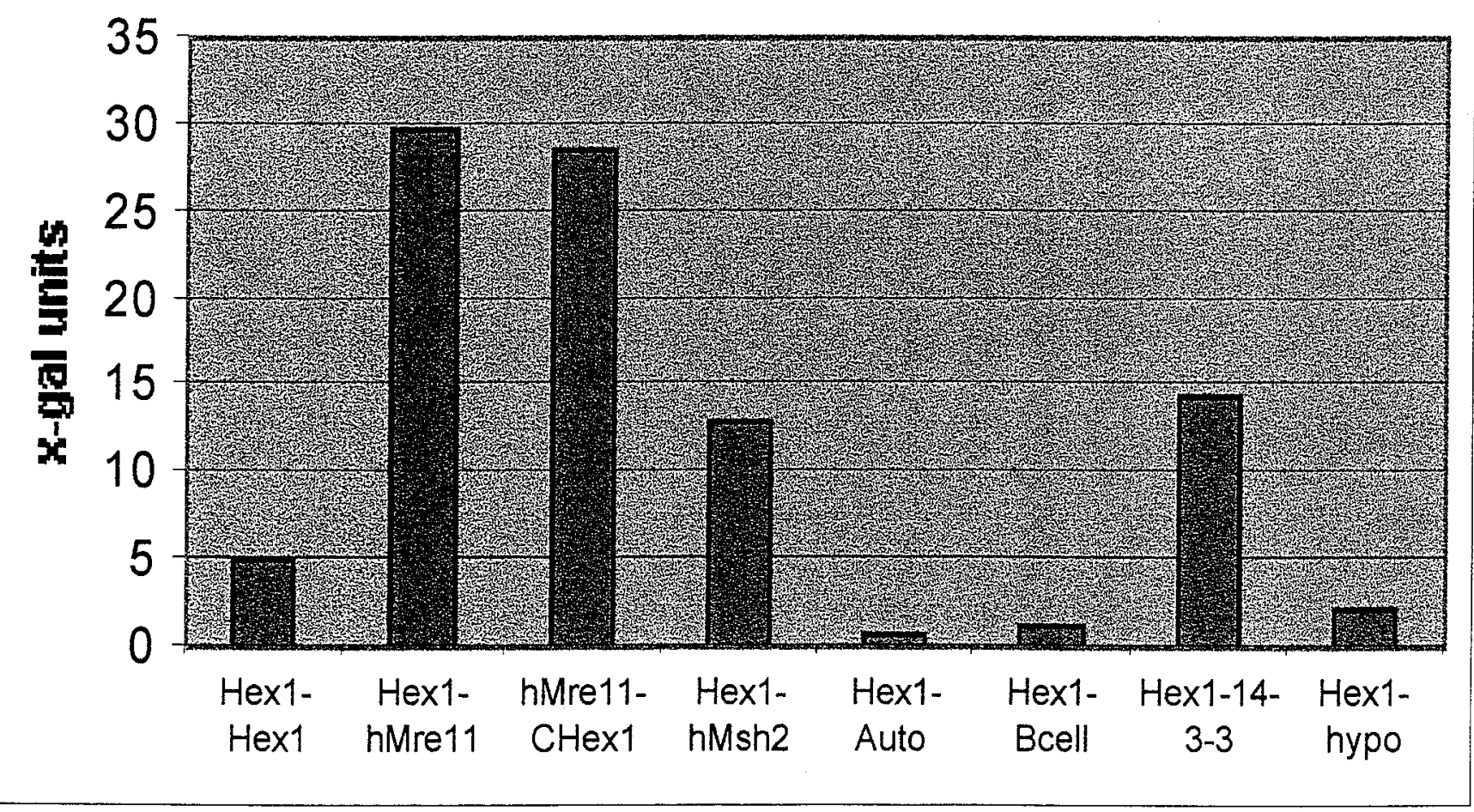

Figure 2. Each bar represent the strenth of interaction between Hex1 and a specific protein. The higher the bar the stronger is the interaction. CHex1 is the trucated protein composed principally of the C-terminal region of Hex1. Hypo correspond to SNF2 like protein. 


\section{C-Terminal Regions of Hex1/hExo1}

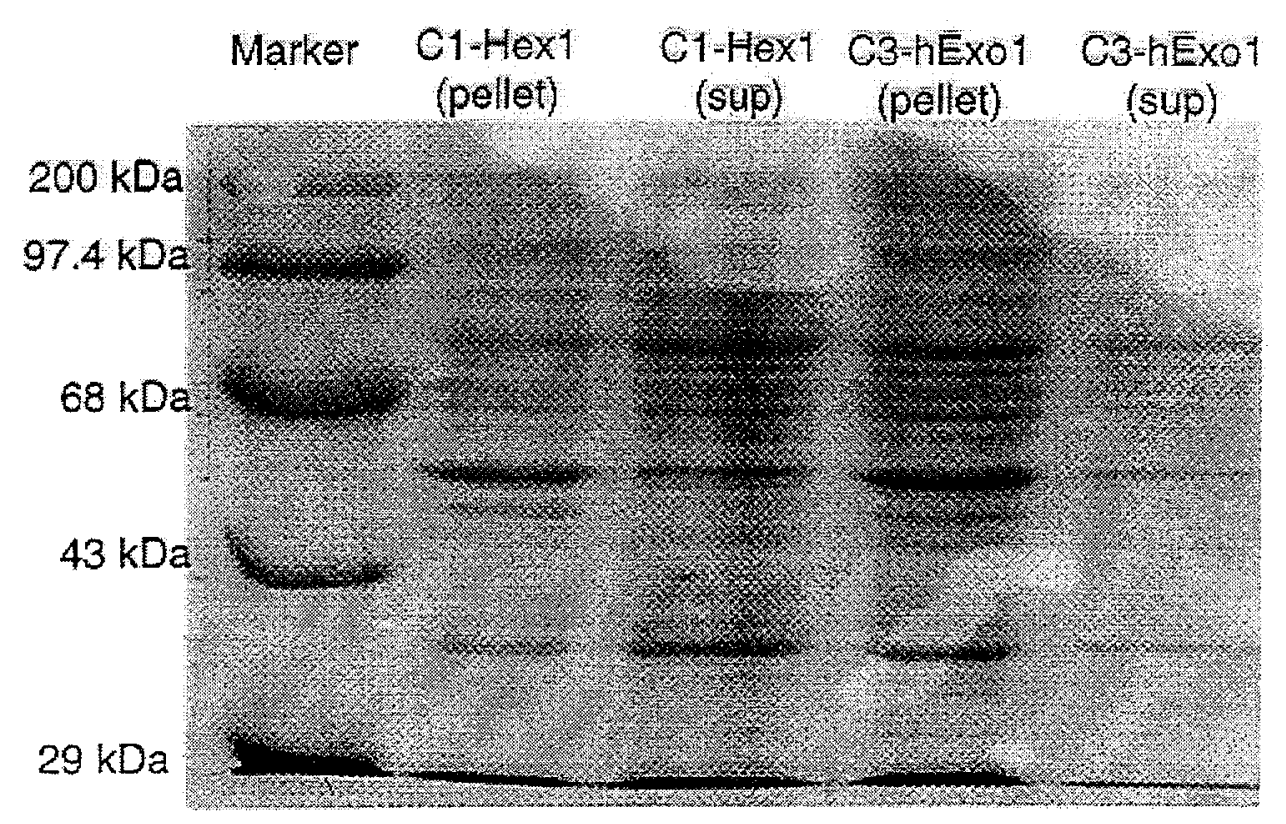

Figure 3. C1-Hex1 corresponds to a polypeptide of 411 amino acids and C3-hExo1 of 454 amino acids. Both polypeptides are approximately $56 \mathrm{kDa}$. Pellet is insoluble proteins and supernatant (sup) is soluble proteins. 


\section{Mismatch Repair}

(a)

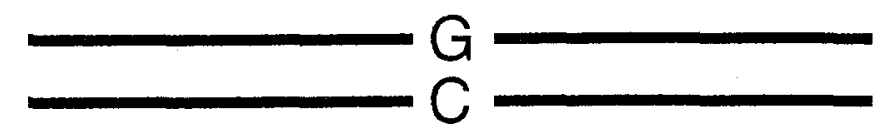

(b)
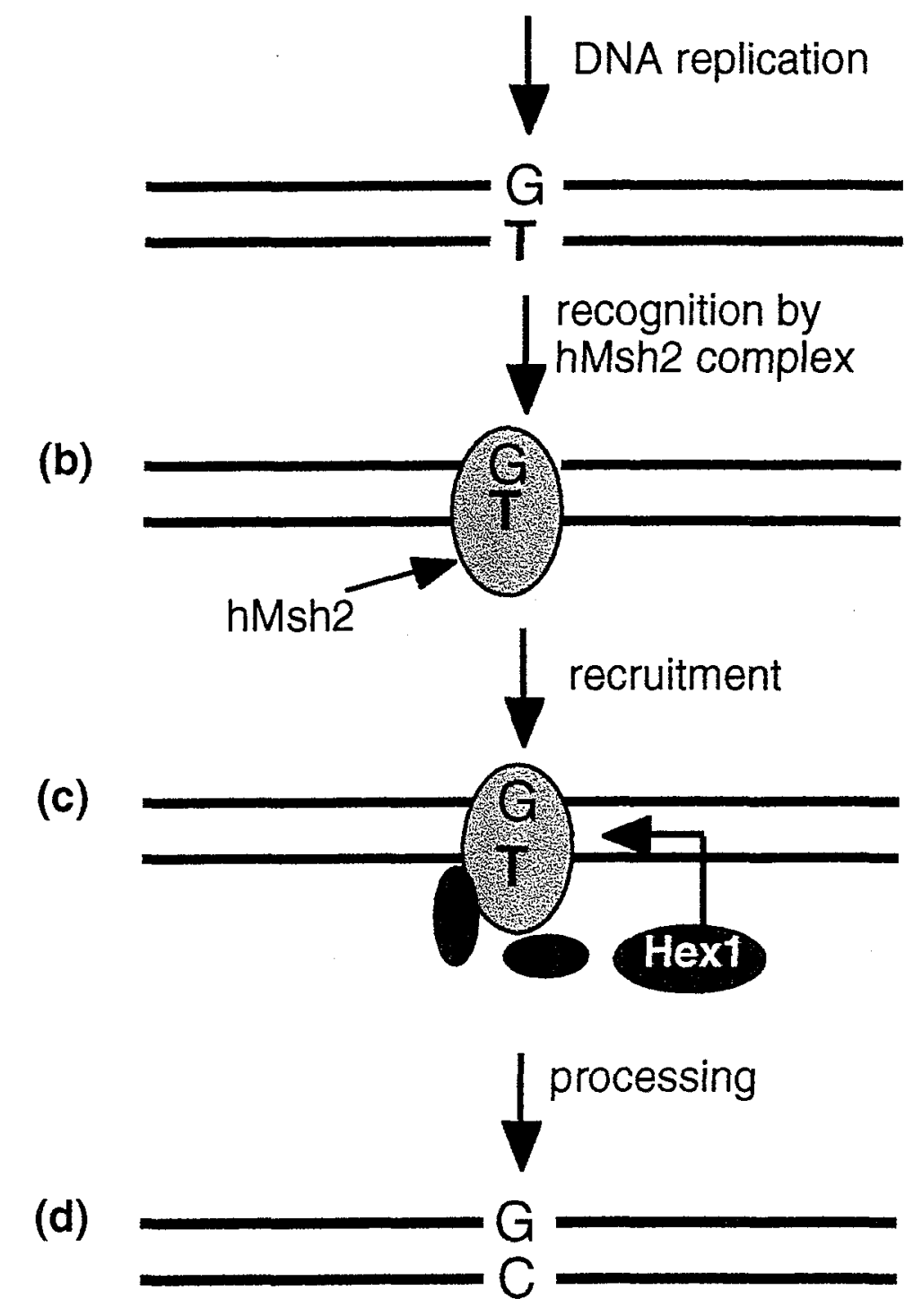

Figure 4. This is a model in which Hex1 and hMsh2 contribute to DNA mismatch repair. The mechanism is divided into four steps: (a) A spontaneous mutation error during DNA replication. In this case guanine (G) is mispaired with thymine ( $T$ ). (b) hMsh2 recognizes the damage and binds to mismatch. A human lacking hMsh2 is more likely to develop Heredetary Nonpolyposis Colorectal Cancer (HNCC). (c) hMsh2 attracts other proteins to excises the mismatch. We have identified an interaction between Hex1 and hMsh2. Hex1 excises a fragment of DNA including the wrong nucleotide. (d) The damage is repaired generating a correct pairing. 


\section{DNA DSB Repair}

(a)

(b)
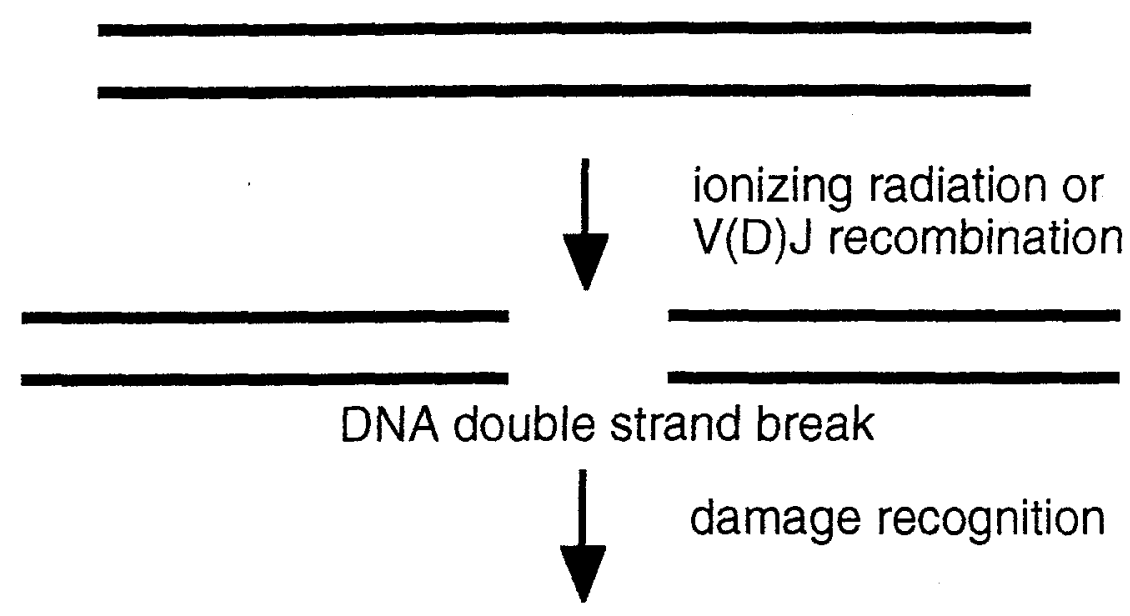

(c)

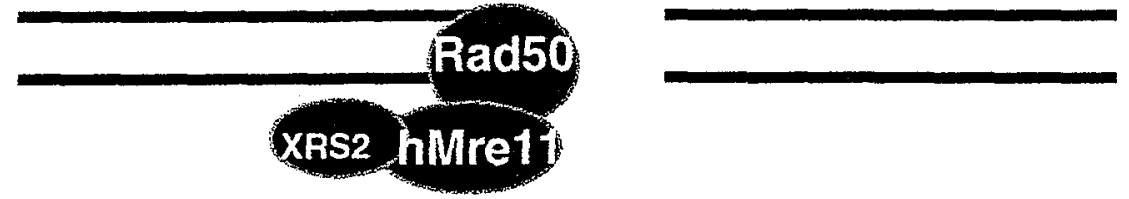

(d)

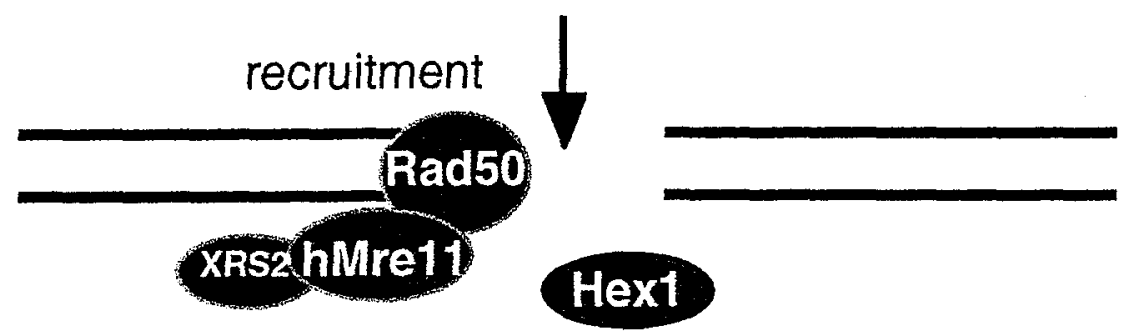

(e)

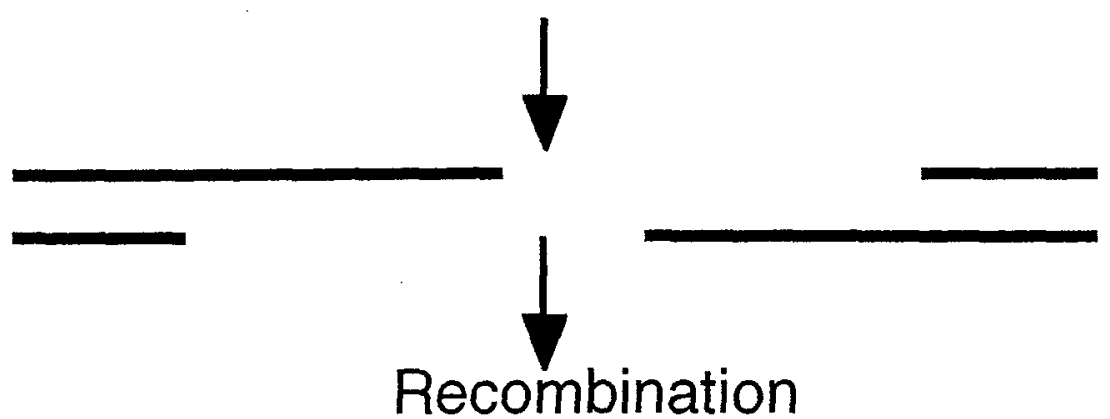

Figure 5. A general model of the role of Hex1, along with some of its protein partners, in DNA double strand break (DSB) repair. The repair mechanism is described in five general steps: (a) A DSB is induced by ioniziong radiation or as an initial step in V(D)J recombination. (b) The complex Rad50-hMre11-XRS2 will bind to DNA ends. (c) The complex atracts others proteins including Hext in which interact with hMre 11 for DNA end processing. (d) $A 3^{\prime} \mathrm{OH}$ single-stranded DNA isi produced and necessary for DNA strand invasion in homologous recombination. (e) DNA is ready for homologous recombination or alternately for nohomologous recombination, where DNA end rejoining will repair the damage. 


\title{
Cascading Modular Biotreatment System (CMBS): From Conceptual Design to Field Tests*
}

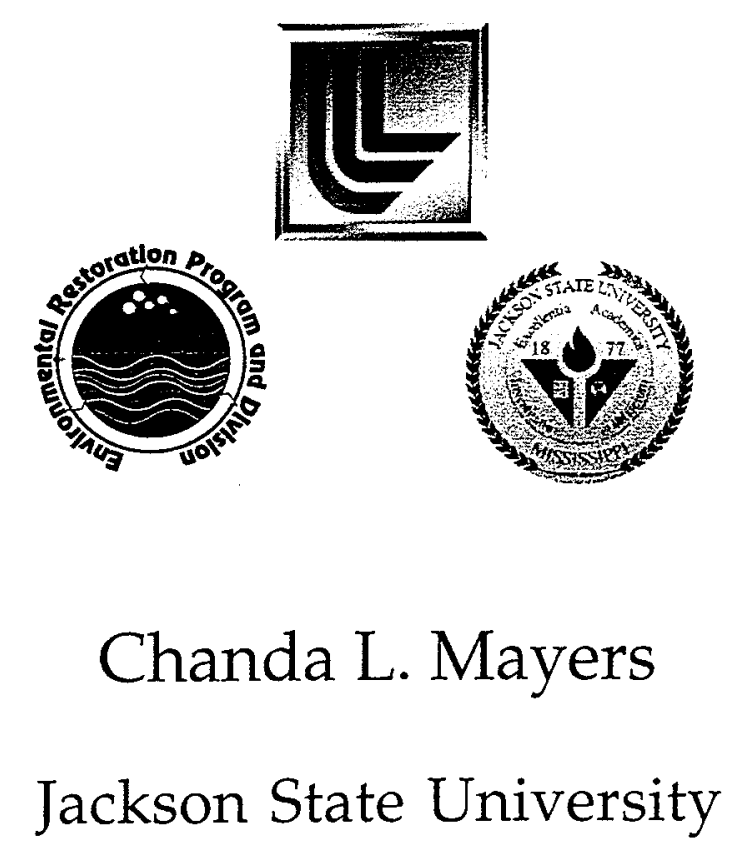

\author{
Environmental Restoration Division \\ Lawrence Livermore National Laboratory
}

May 27, 1999

Prepared in partial fulfillment of the requirements of the Undergraduate Research Semester under the direction of Paula Krauter, Research Mentor, in the Lawrence Livermore National Laboratory.

*This research was supported in part by an appointment to the U.S.

Department of Energy, Office of Defense Programs, Undergraduate Research Semester (hereinafter called URS) Program administered by University of California, LLNL under Contract W-7405-Eng-48 with Lawrence Livermore National Laboratory. 


\title{
Cascading Modular Biotreatment System: From Conceptual Design to Field Tests
}

\author{
Chanda L. Mayers \\ Jackson State University \\ B.S. Biology, December 1998
}

\section{DESCRIPTIVE ABSTRACT}

Elevated nitrate concentrations in ground water at Lawrence Livermore National Laboratory's (LLNL) Site 300 may pose toxicological and ecological effects. This study evaluated the efficiency of phytoremediation in a constructed wetland to remove nitrate from ground water. A Cascading Modular Biotreatment System (CMBS) was designed and is currently undergoing testing at the Livermore site. Phytoremediation proved effective in removing nitrate from ground water. Since the rate of nitrate removal is influenced by climate and growth media, optimal operational criteria are still under evaluation. 


\section{INTRODUCTION}

Nitrate $\left(\mathrm{NO}_{3}\right)$ concentrations above the maximum contaminant level (MCL) were found in ground water at several locations at Lawrence Livermore National Laboratory's Site 300 (Fig. 1). Nitrate contamination is primarily caused by agriculture fertilization practices but may also be caused by many confined animal operations, wastewater treatment plants, explosive manufacturers, munitions dumps and handling facilities, and industries that use nitrogen compounds. Nitrate contamination has shut down more public water supply wells than any other contaminant and is probably the most consumed water contaminant. Elevated nitrate concentrations in ground water may cause toxicological and ecological. Elevated nitrate concentrations in drinking water have been linked to methemoglobinemia (blue-baby syndrome), a potentially fatal disease primarily of infants. Because of this human-health hazard, the US Environmental Protection Agency set the nitrate $\mathrm{MCL}$ for drinking water at $45 \mathrm{mg} / \mathrm{L}$ (ppm) expressed as nitrate. It was suggested that methemoglobin is probably formed in the intestinal tract of an infant when bacteria convert the nitrate ion to nitrite (1). One nitrite molecule then combines with two molecules of hemoglobin to form methemoglobin. Because infants' stomachs are relatively alkaline, more nitrate is converted to nitrite in the infant stomach than in the adult stomach. Infant hemoglobin reacts to form methemoglobin easier than adult hemoglobin (2). This reaction causes a slow suffocation of the infant that may lead to death $(3,4)$. There are numerous references to adverse health affects from the consumption of nitrate contaminated water besides methemoglobenemia. These health effects may include spontaneous miscarriages, non-Hodgkin's lymphoma, childhood diabetes, teratogenic development of offspring, and certain cancers (5). Elevated nitrate levels are also known to cause nitrate poisoning in animals that forage (6). Although associations between elevated nitrate levels in drinking water and these health effects have been shown, they have yet to be proven. At specific locations on LLNL's Site 300, nitrate levels exceeded $45 \mathrm{mg} / \mathrm{L}$.

There are several possible sources for the excessive nitrate levels in Site 300 ground water. These sources include: (1) natural concentrations from rocks, soil, minerals, and plant decomposition, (2) contamination from inorganic fertilizers and animal wastes and, (3) contamination from technical operations such as the manufacture or testing of high explosives. The application of phytoremediation (the use of plants to degrade or contain contaminants in soil, ground water, streams, or wastewater) is an inexpensive and environmentally friendly approach to decontamination. However, the appropriateness of phytoremediation for the removal of nitrate from ground water requires evaluation. A Cascading Modular Biotreatment System (CMBS) was designed to simulate a constructed wetland, and it is currently being tested for possible use at Site 300 (Fig. 2). These tests are expected to demonstrate the efficacy of phytoremediation to remove nitrate from ground water. 


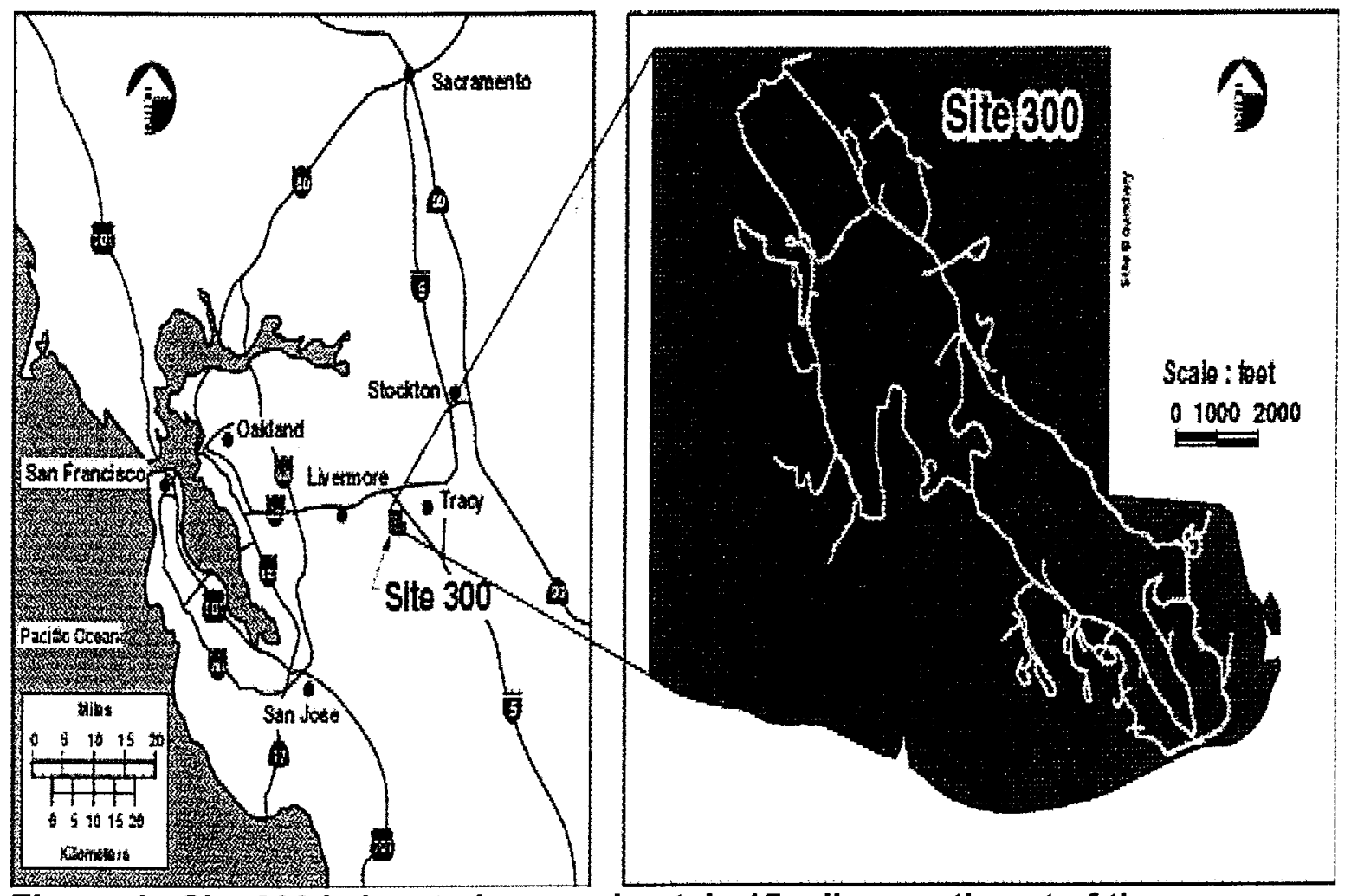

Figure 1. Site 300 is located approximately 15 miles southeast of the Livermore Site. 


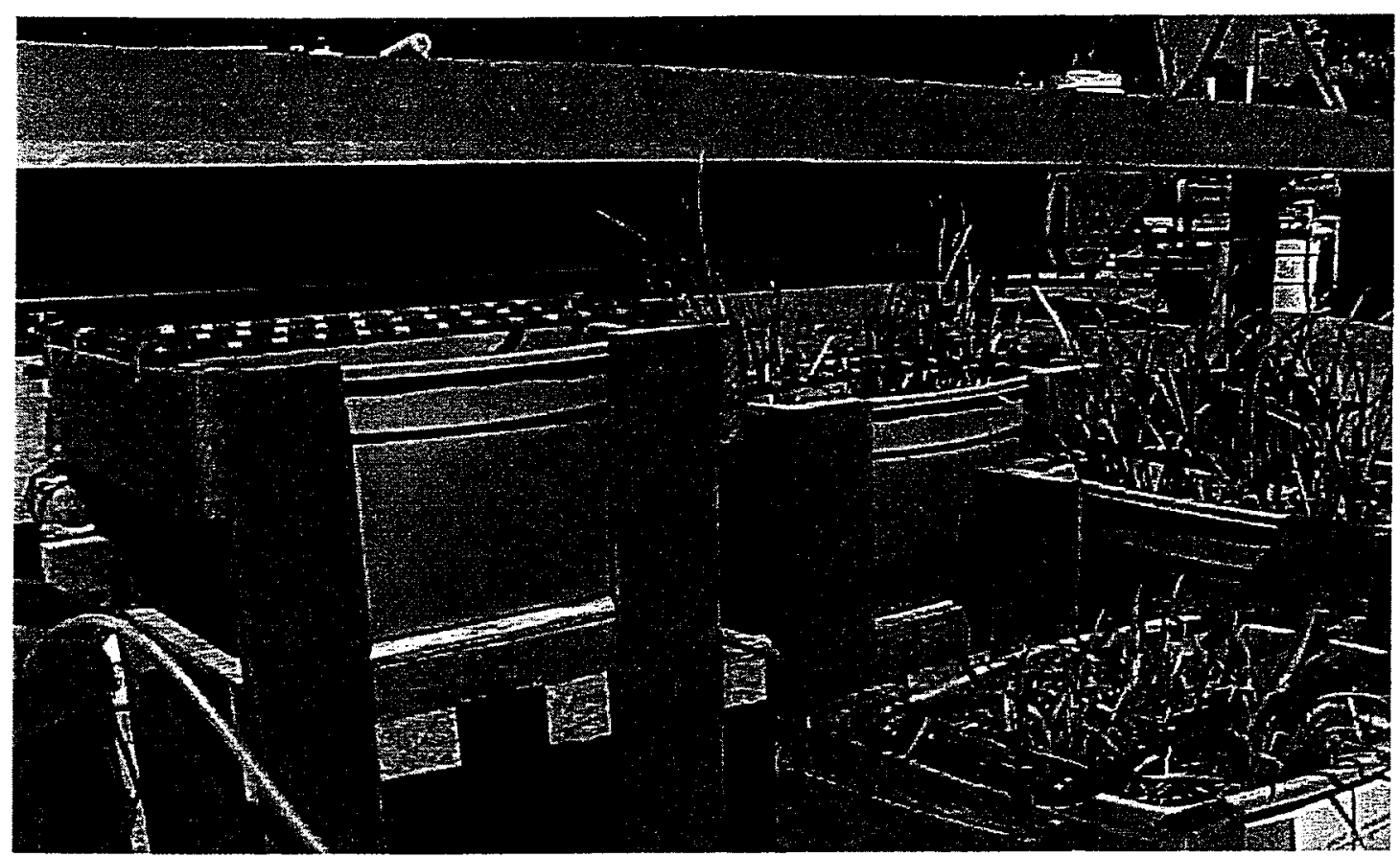

Figure 2. The Cascading Modular Biotreatment System is undergoing testing at the Livermore site. 


\section{DESIGN METHODS}

The CMBS is a modular, mobile unit for biologically treating ground water nitrate (Fig. 3). The CMBS is designed to utilize gravity flow where untreated ground water slowly drips into each of the four treatment pods via perforated tubing. Each pod contains filters of medium grain gravel and sand. Because denitrification requires an anaerobic environment, the tubing is very close to the gravel in each pod to prevent the ground water from becoming saturated with oxygen. Untreated ground water is pumped from a 55 gallon drum and is drained into perforated tubing so that it would slowly trickle into the first treatment pod and filter to the bottom. The ground water is then forced by the pressure from the filtered ground water through a conduit to empty into the next series of perforated piping of the subsequent pod. The water then flows to pods containing suitable plants such as bulrushes (Scirpus spp.), cattails (Typha spp.) and sedges (Carex spp.). These plants are native to the area where the CMBS will be located. Pod 1 (the control) contains gravel only. Pod 2 is composed of bulrushes and gravel. Pod 3 is composed of cattails and gravel. Pod 4 is composed of sedges and gravel. The effluent water from Pod 4 is accumulated in a tank for discharge. Each treatment pod has a small diameter, about four feet, because of the expected low volume flow. The total retention time through the system is approximately twenty hours.

As the untreated ground water filters through the gravel in each pod, denitrifying bacteria utilize nitrate in cellular respiration. The plants in Pods 2,3 , and 4 take up the nitrate ions, which are converted to ammonia in the roots and/or shoots for use in protein synthesis (Equation 1).

\section{(Equation 1)}

$$
\mathrm{NO}_{3}^{-} \rightarrow \mathrm{NO}_{2}^{-} \rightarrow \mathrm{NH}_{4}^{+} \rightarrow \text { amino- } \mathrm{NH}_{4} \rightarrow \text { protein }
$$

Denitrifying bacteria reduce nitrate to nitrite that is further reduced to nitrous oxide. Nitrogen gas is the final product formed by microorganisms in the rhizospheres (Equation 2).

\section{(Equation 2)}

$$
\mathrm{NO}_{3}^{-} \rightarrow \mathrm{NO}_{2}^{-} \rightarrow \mathrm{NO} \rightarrow \mathrm{N}_{2} \mathrm{O} \rightarrow \mathrm{N}_{2}(\mathrm{~g})
$$




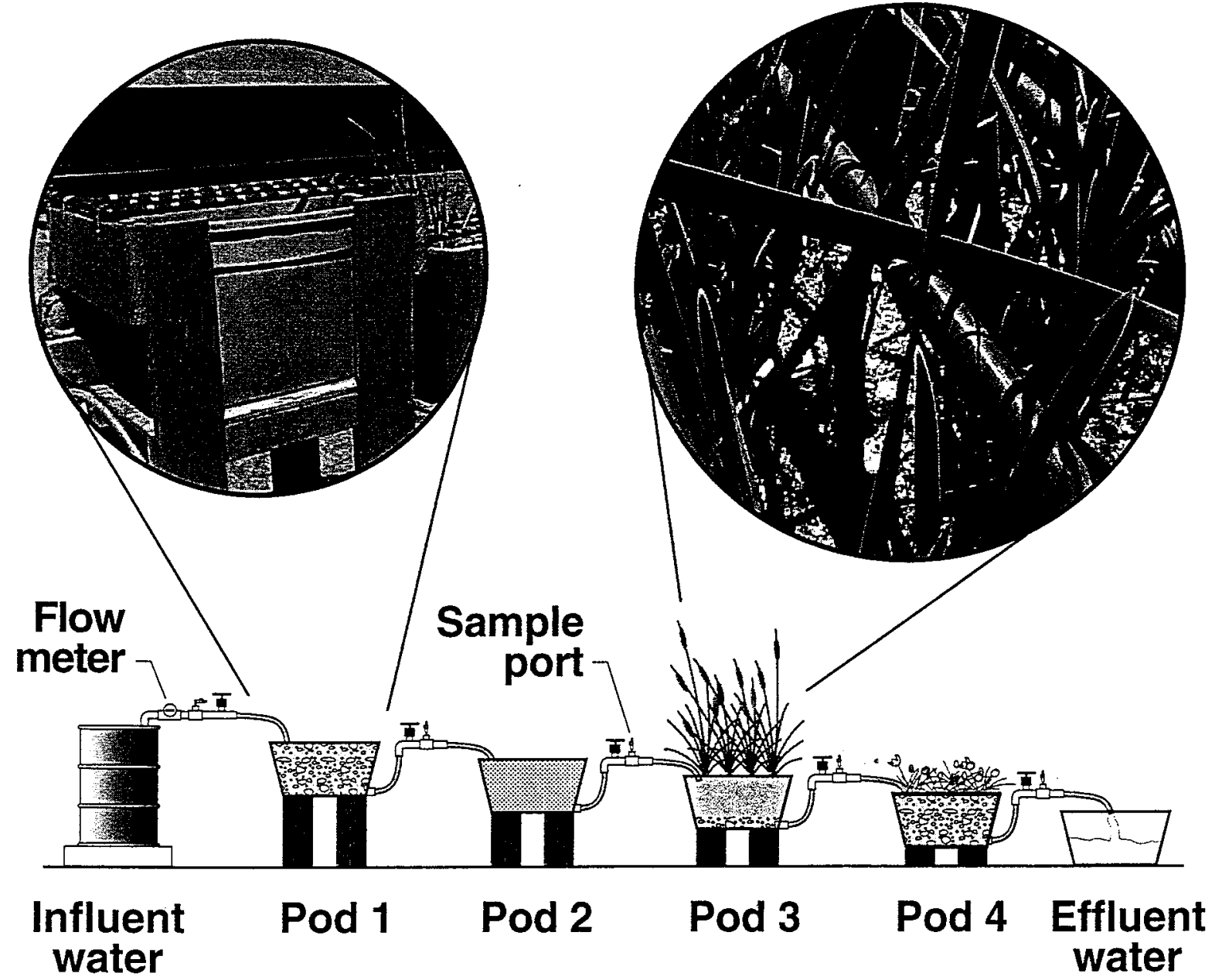

Figure 3. The Cascading Modular Biotreatment System is a modular, mobile unit for biologically treating ground water. 


\section{EXPERIMENTAL METHODS}

- Determine flow rate by measuring effluent flow

- Analyze nitrate, nitrite, and phosphate concentrations and dissolved oxygen using the Chemetrics ${ }^{\top M}$ test kit (EPA method 300.0) from samples at each sample port (Fig. 4)

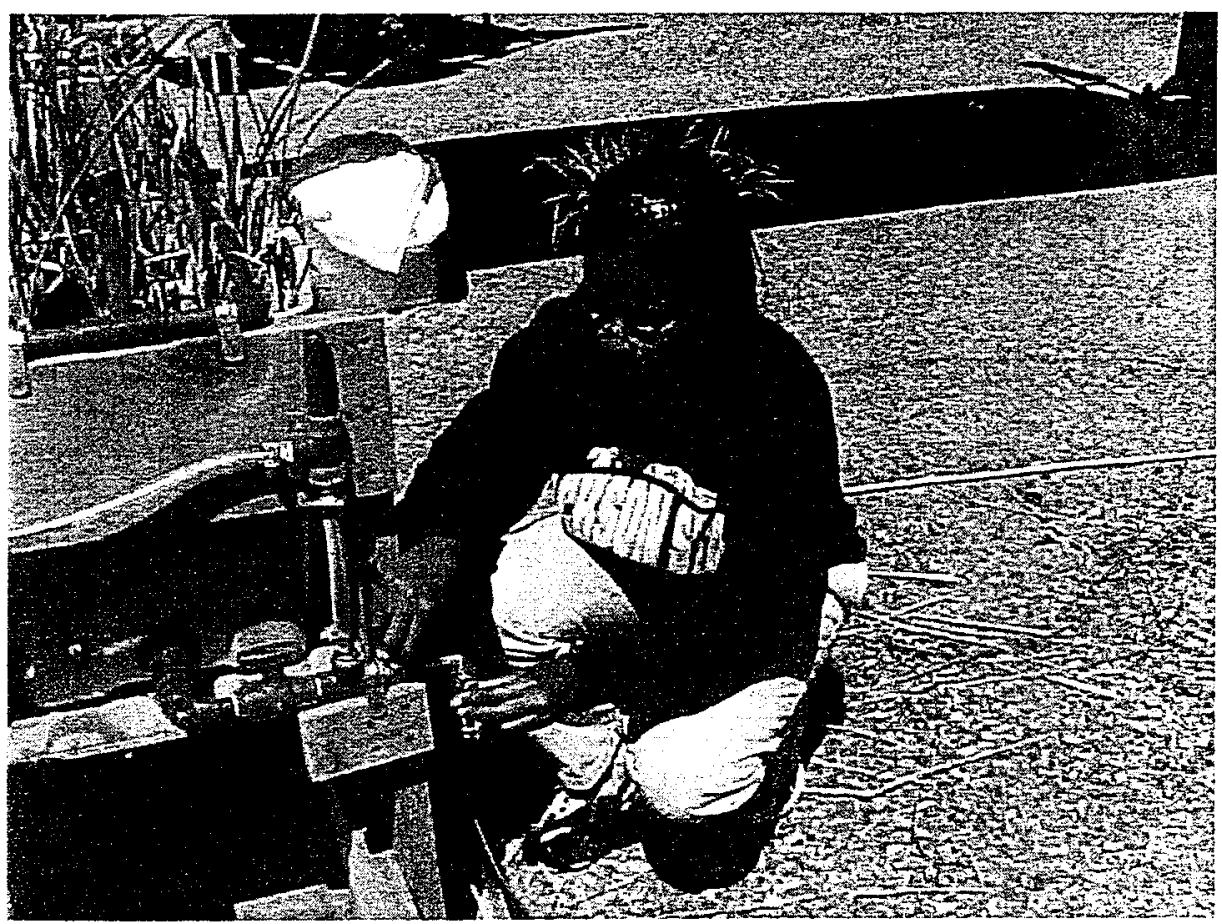

Figure 4. Water sampling at the CMBS.

- Analyze total organic carbon of each sample (standard method 5310)

- Record temperature, conductivity, oxidation/reduction potential, and $\mathrm{pH}$ using a YSI multi-probe ${ }^{\mathrm{TM}} \mathrm{pH}$ meter

- Calculate percent of nitrate removed

- Determine optimum parameters for nitrate removal 
The ground water at Site 300 has a high buffering capacity. This characteristic makes working with the ground water more difficult because of the high alkalinity. Ground water from test well 854-08 was chosen as the source for this study because it is a relatively clean well (no interference from other chemical contaminants) with an elevated nitrate concentration. Figure 5 shows the location of W-854-08 and the direction of ground water flow in the local region.

To ensure that there is no interference from other chemicals in test well 854-08, a list of analytes above the detection level was compiled (Table 1).

\begin{tabular}{|c|c|c|}
\hline Analyte & Unit & Result \\
\hline $\begin{array}{l}\text { Total Alkalinity as } \\
\left(\mathrm{CaCO}_{3}\right)\end{array}$ & $\mathrm{mg} / \mathrm{L}$ & 180 \\
\hline Barium & $\mathrm{mg} / \mathrm{L}$ & 0.038 \\
\hline Calcium & $\mathrm{mg} / \mathrm{L}$ & 25 \\
\hline Chloride & $\mathrm{mg} / \mathrm{L}$ & 160 \\
\hline Chloroform & $\mu g / L$ & $<0.5$ \\
\hline Copper & $\mathrm{mg} / \mathrm{L}$ & $<0.05$ \\
\hline Fluoride & $\mathrm{mg} / \mathrm{L}$ & 0.38 \\
\hline Freon 113 & $\mu \mathrm{g} / \mathrm{L}$ & $<0.5$ \\
\hline PCE & $\mu \mathrm{g} / \mathrm{L}$ & $<0.5$ \\
\hline Perchlorate & $\mu \mathrm{g} / \mathrm{L}$ & $<4$ \\
\hline $\mathrm{pH}$ & -- & 7.6 \\
\hline TCE & $\mu \mathrm{g} / \mathrm{L}$ & $<0.5$ \\
\hline Arsenic & $\mathrm{mg} / \mathrm{L}$ & 0.032 \\
\hline Beryllium & $\mathrm{mg} / \mathrm{L}$ & 0.092 \\
\hline Chromium & $\mathrm{mg} / \mathrm{L}$ & 0.002 \\
\hline Lead & $\mathrm{mg} / \mathrm{L}$ & 0.003 \\
\hline Magnesium & $\mathrm{mg} / \mathrm{L}$ & 18 \\
\hline Nitrate (as $\mathrm{NO}_{3}$ ) & $\mathrm{mg} / \mathrm{L}$ & 62 \\
\hline Ortho-Phosphate & $\mathrm{mg} / \mathrm{L}$ & 0.082 \\
\hline Potassium & $\mathrm{mg} / \mathrm{L}$ & 6 \\
\hline Selenium & $\mathrm{mg} / \mathrm{L}$ & 0.008 \\
\hline Sodium & $\mathrm{mg} / \mathrm{L}$ & 160 \\
\hline Sulfate & $\mathrm{mg} / \mathrm{L}$ & 25 \\
\hline
\end{tabular}

Table 1. Analytes above non-detect level for test well 854-08 (W-854-08). 


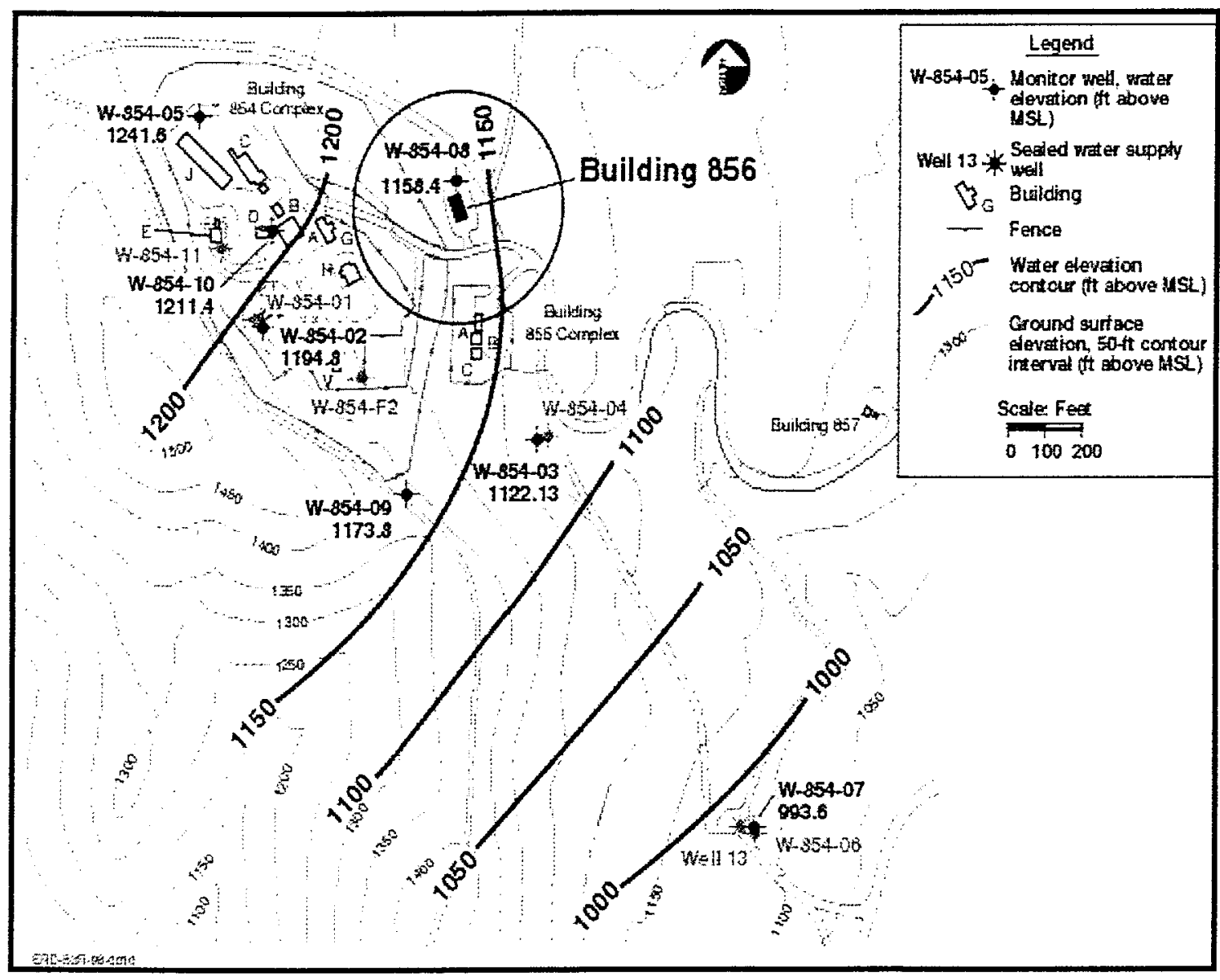

Figure 5. Building 854 ground water monitoring wells at Site 300. 


\section{Results and Discussion}

Phytoremediation has proven to remove nitrate from ground water. However, time requirements for phytoremediation are site- and mediaspecific. Because of the newness of the system, the plants used in the CMBS required more time for acclimation to test well 854-08 ground water. The unseasonably cold atmospheric temperatures also influenced the nitrate removal rate (Fig. 7). Optimum temperatures for wetlands are $29-32{ }^{\circ} \mathrm{C}$. During our preliminary tests, the average daily atmospheric temperature was only $9.8^{\circ} \mathrm{C}\left(49.8^{\circ} \mathrm{F}\right), 2^{\circ} \mathrm{C}$ less than the same time period at this site during the last two years. The current optimal operational conditions for this system are being determined.

Despite the cold atmospheric temperatures during February 1 through May 3, 1999, the CMBS was able to reduce the nitrate (as nitrate) concentration in W-854-08 ground water to a concentration below the detection level of 2 $\mathrm{mg} / \mathrm{L}$ (Table 2 and Fig. 6).

The smallness and simplicity of the system make this an attractive technology. These units will be placed on a gentle or steep slope so that the water is gravity fed through the system resulting in very low energy requirements. This system is cost efficient and requires very little maintenance--only occasional harvesting of the plants is required. Also, if the water flow stops, the system will not fail because it only needs to stay saturated to keep functional. Another advantage to this remediation technique is that some plants will take-up metals and other contaminants, possibly explosives, in addition to the nitrate.

Future modifications include: (1) adjusting flow rate for optimal hydraulic retention time, (2) installing solar panels to increase water temperature during colder seasons, and (3) testing various genera of native wetland plants for optimal nitrate removal.

\begin{tabular}{|c|c|c|c|c|c|c|}
\hline $\begin{array}{c}\text { Sample } \\
\text { port }\end{array}$ & $\begin{array}{c}\text { Nitrate } \\
\left(\mathrm{NO}_{3}^{-}\right)\end{array}$ & $\begin{array}{c}\text { Dissolved } \\
\text { Oxygen }\end{array}$ & $\mathrm{pH}$ & $\mathrm{eH}$ & Temperature & Conductivity \\
\hline Influent & $60.5 \mathrm{mg} / \mathrm{L}$ & $5.7 \mathrm{mg} / \mathrm{L}$ & 7.46 & $181 \mathrm{mV}$ & $50^{\circ} \mathrm{C}$ & $1.35 \mathrm{n}$ \\
\hline $\mathrm{SP} 2$ & $61.0 \mathrm{mg} / \mathrm{L}$ & $3.3 \mathrm{mg} / \mathrm{L}$ & 8.03 & $162 \mathrm{mV}$ & & $0.64 n$ \\
\hline SP3 & $26.5 \mathrm{mg} / \mathrm{L}$ & $1.1 \mathrm{mg} / \mathrm{L}$ & 7.72 & $158 \mathrm{mV}$ & & $0.74 \mathrm{~m}$ \\
\hline $\mathrm{SP} 4$ & $2.50 \mathrm{mg} / \mathrm{L}$ & $0.8 \mathrm{mg} / \mathrm{L}$ & 7.20 & $134 \mathrm{mV}$ & & $0.01 \mathrm{mmhos}$ \\
\hline Effluent & $2.00 \mathrm{mg} / \mathrm{L}$ & $2.5 \mathrm{mg} / \mathrm{L}$ & 7.14 & $122 \mathrm{mV}$ & $16.70^{\circ} \mathrm{C}$ & $0.03 \mathrm{mmhos}$ \\
\hline
\end{tabular}

Table 2. Nitrate concentration reduction after each treatment pod.

$\mathrm{SP}=$ sample port 


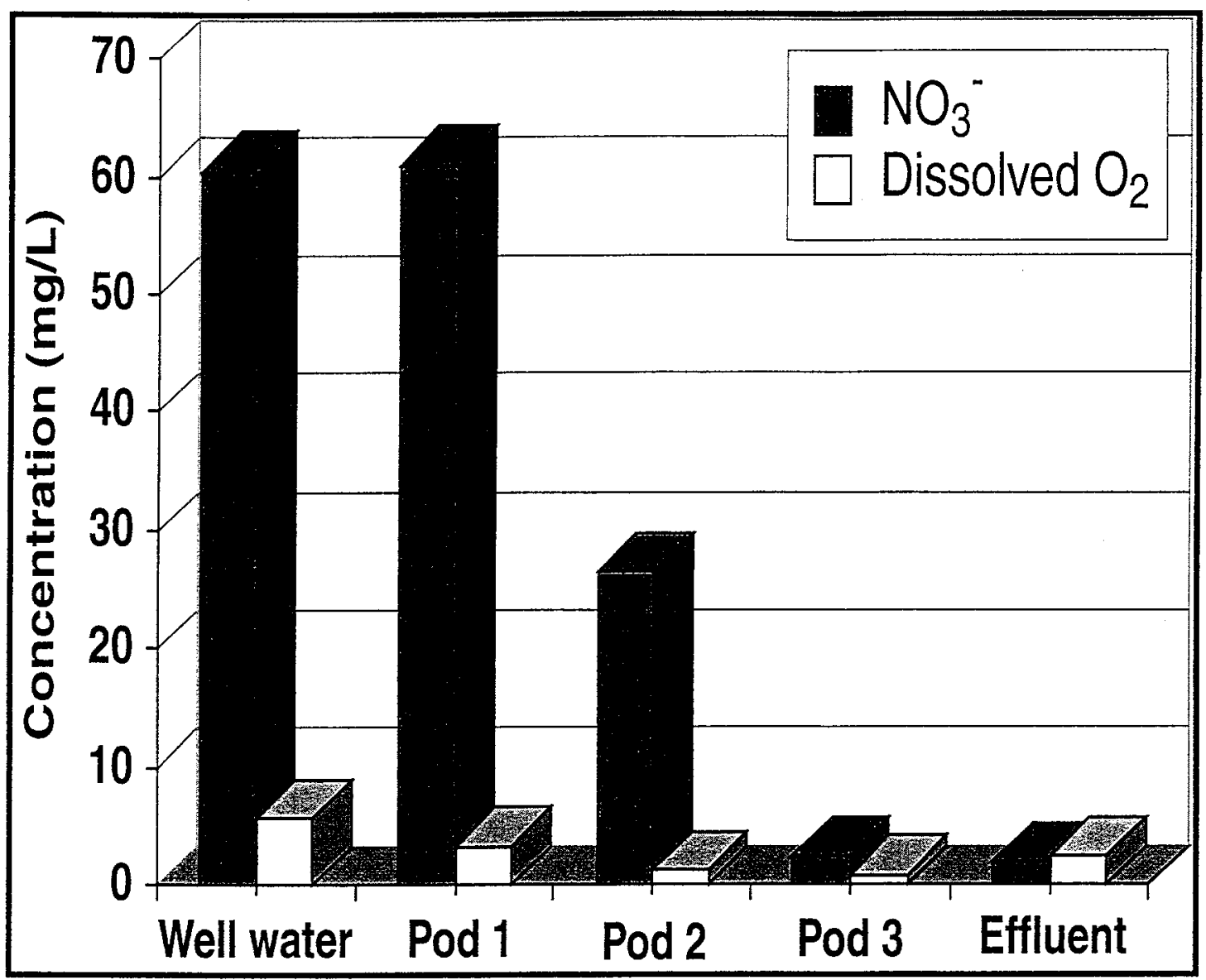

Figure 6. The nitrate concentration was reduced after each treatment pod. 


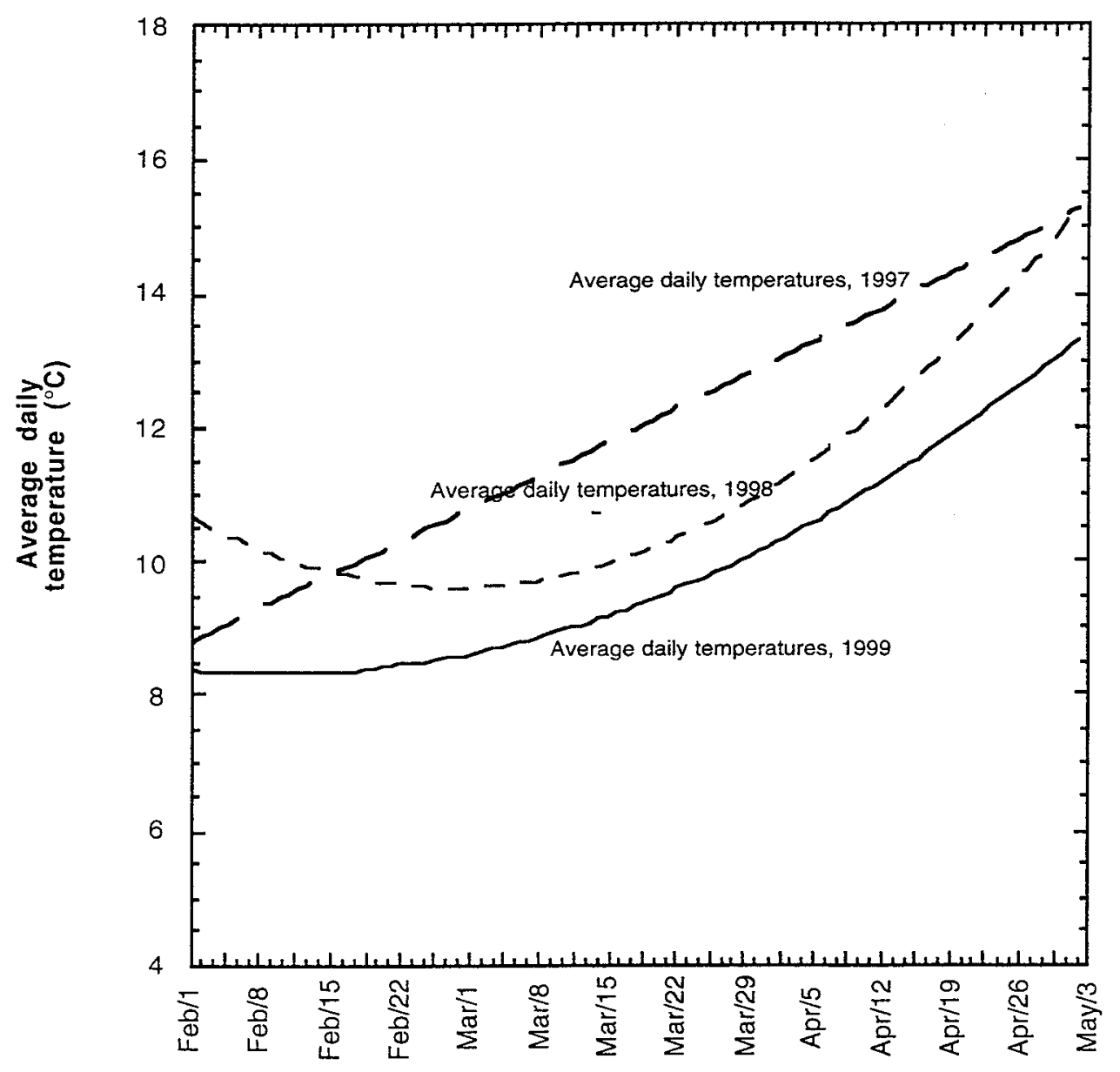

Figure 7. The unseasonably cold average daily temperature of $9{ }^{\circ} \mathrm{C}$ influenced the nitrate removal rate. Optimal wetland temperatures range from $28^{\circ} \mathrm{C}$ to $32{ }^{\circ} \mathrm{C}$. 


\section{References}

1. Comly, HH (1987) "Cyanosis in Infants Caused by Nitrates in Well

Water". Journal of the American Medical Association, v. 257, p. 2788-2792.

2. Environmental Working Group (1996) "Pouring it On: Health Effects of Nitrate Exposure". URL:

http://www.ewg.org/pub/home/Reports/Nitrate/NitrateHealth.html.

3. Finley, B, (1990) "Well-water Nitrates Endanger N. Colorado". Denver (Colorado) Post, 16 November.

4. Gustafson, DI (1993) Pesticides in Drinking Water. Van Hostrand Reinhold, New York, p. 241.

5. Tsay, Y-F, (1998) "Nitrate Uptake and Transport in Plants". URL:

http://www.sinica.edu.tw/imb/ressearcher/Yi-Fan-Tsay/Yii-Fan-Tsay.htm.

6. Lardy, G, and Stotltenow, C (1998) "Nitrate Poisoning of Livestock". URL: http://ndsuext.nodak.edu/extpubs/ansci/livestoc/v839w.htm.

\section{Acknowledgments}

The project was made possible by the work of the following people: Ed Folsom, Kim Heyward, Tina Carlsen, and Steve Gregory. 


\title{
Detection and Identification of Biological Warfare Agents
}

\author{
Adebomi Omikunle \\ Mississippi State University \\ Earth and Environmental Sciences Directorate
}

\begin{abstract}
The overall goal of this project is to use mass spectrometry to develop rapid, realtime, and facile methods for remote detection of biological warfare agents in the atmosphere (1). To facilitate these aims, studies were conducted using simulants of Bacillus anthracis (our model organism and the causative agent of anthrax). The major spore coat proteins of the simulants were isolated and characterized, and are being analyzed by mass spectrometry. Results should provide unique molecular signatures enabling the identification of similar biological warfare agents in sample aerosol.
\end{abstract}




\section{INTRODUCTION}

Why use biological agents in warfare? The answer is simple: they are easily accessible and cheap to produce. Potentially, there are numerous pathogenic organisms that could be considered for use as bioterrorism agents; fortunately, only a handful are capable of inflicting serious damages. This is due to several reasons: (1) many organisms are not easily deployed for biological weaponry, (2) some organisms cannot survive outside their natural hosts, (3) some are obligate anaerobes, (4) some are sensitive to temperature, and(5) a number of other external factors may affect the viability of some (3).

The most effective agents are spores. Sporulation occurs when the agent (bacteria) ceases to grow due to the exhaustion of an essential nutrient in the media or environment. Spores are very hardy and can resist physical and chemical agents due to the presence of a seven layered peptidoglycan cell wall and calcium dipicolinate core. They are easy to aerosolize, and the aerosols readily penetrate the respiratory system if they are $1-10 \mu$ in diameter (2). They can remain in this latent phase for years and quickly revert back to vegetative cells under favorable conditions to cause disease.

The use of biological weapons in warfare can probably be dated back to early history when European settlers gave (intentionally or unintentionally) the Native Americans blankets contaminated with the small pox virus (4). However, these days, the threat of intentional use of biological agents is a scary reality. In 1984, the Rajneesh cult near Antelope, Oregon contaminated salad bars of local restaurants with Salmonella typhi ( the causative agent of typhoid fever) to influence the outcome of a local election. Over 750 people were poisoned as a result of this. Also, during the Persian Gulf war of 1991, Iraq assembled missiles containing Bacillus anthracis (the causative agent of anthrax) (2). Due to the new wave of terrorism in the United States and around the world, it can be speculated that targets for acts of bioterrorism would be densely populated public places such as airports, subway systems, or sports stadiums. Currently, the United States does not possess any real-time capability to detect aerosols in the field. The military are provided with protective gear, trained to respond quickly to a biological attack and are, in most cases, vaccinated against some of the agents. The civilian public on the other hand lack the necessary training and protective gear and would be rendered defenseless in the event of an attack $(1,2)$. Because of this potential threat, the government has been investing in promising approaches for development of technology that would detect biological agents in real-time and in a rapid and facile manner. Some of these approaches as reported by the U.S. Chemical and Biological Defense Information Analysis Center in Aberdeen include: PCR, flow cytometry, mass spectrometry and immunoassay technologies (2). 


\begin{abstract}
APPROACH
This project applied mass spectrometry (MS) for real-time detection of biological warfare agents. The overall goal of this project was to determine whether different biological particles yielded different mass spectrometry signatures. The results obtained would be used as the basis for the development of a mass spectrometer that will distinguish between different organisms and even species within the same genus in real-time.

The analogs of Bacillus anthracis used in this study were: Bacillus subtilis, Bacillus subtilis var. niger, Bacillus cereus, and Bacillus thuringiensis. This study was aimed at purifying and characterizing the spore coat proteins of the simulants using sodium dodecyl sulfate (SDS)-polyacrylamide gel electrophoresis (PAGE), ion-exchange chromatography, electroelution techniques, and mass spectrometry.
\end{abstract}




\section{METHODS}

\section{Sporulation of the agents}

The organisms were each streaked onto a nutrient agar plate and incubated overnight at $30^{\circ} \mathrm{C}$. An isolated colony from each was then transferred into different flasks containing nutrient broth. These flasks were incubated overnight at $30^{\circ} \mathrm{C}$ with agitation. Contents of each were then transferred to separate flasks containing $1 / 4 \mathrm{X}$ tryptone-yeast (TY) media and incubated for at least four days (5). Sporulation in the TY media was monitored by sampling and staining samples using the Schaeffer and Fulton modification of the Wirtz spore staining method (6).

\section{Isolation of the spore coat proteins}

The spores in each flask were then harvested by centrifugation (7000 rpm for $20 \mathrm{~min})$. The pellets were each washed twice $(7000 \mathrm{rpm}$ for $20 \mathrm{~min}$ ) with sterile $1 \mathrm{M} \mathrm{NaCl}$ followed by de-ionized water. The cells (pellets) were resuspended in $50 \mathrm{mM}$ TRIS buffer, pH 7.0 and treated with $250 \mu \mathrm{g} / \mathrm{ml}$ of lysozyme for $1 \mathrm{hr}$ at $37^{\circ} \mathrm{C}$ in a water bath with gentle agitation (7). After this, the spores were either dried or their coat proteins removed for MS analysis. For coat protein removal, the mixture was centrifuged and washed and re-suspended in $50 \mathrm{mM}$ TRIS, $\mathrm{pH}$ 7.0. This was then centrifuged and the spores were resuspended in $50 \mathrm{mM}$ TRIS, $\mathrm{pH} 8.0,8 \mathrm{M}$ urea, $1 \%$ SDS and $50 \mathrm{mM}$ dithiothreitol (DTT). This suspension was incubated for $1 \mathrm{hr}$ at $37^{\circ} \mathrm{C}$ to remove the coat proteins. The proteins were separated by centrifugation and dialyzed against 50 mM TRIS, pH 8.0, and $1 \mathrm{mM}$ phenylmethyl-sulfonyl fluoride.

\section{Purification of the coat proteins}

Upon completion of dialysis, aliquots of the proteins from each organism were separately precipitated by mixing with equal volumes of acetone. This was stored overnight at $-20^{\circ} \mathrm{C}$. The samples were later removed from the freezer, centrifuged at $\sim 14,000 \mathrm{rpm}$ for $10 \mathrm{~min}$ and the acetone supernatant decanted. The coat proteins followed two paths from here:

- $\quad$ Some portions were resuspended in buffer and separated by ion-exchange chromatography using SP sepharose, $50 \mathrm{mM} \mathrm{NaPO}_{4}$ buffer, $\mathrm{pH} 7.5$, and a linear $\mathrm{NaCl}$ gradient of $0-1 \mathrm{M}(8)$. The fractions obtained were then analyzed by SDS-PAGE $(7,9,10)$.

- The remaining portions were resuspended in SDS-PAGE buffer and DTT, centrifuged briefly, heated to $95^{\circ} \mathrm{C}$ for $5 \mathrm{~min}$ to denature the proteins, centrifuged again, and loaded on a 15\% SDS-PAGE gel to undergo electrophoresis (7). 
The gels used in the above paths were stained using either Coomassie blue or copper stains. Gels to be eluted were stained using copper stain.

For elution, bands were excised from the gel (keeping track of the origin of each one), destained, and stored in minimal volumes of elution buffer. The proteins in them were then eluted using a gel electroeluter (11), collected, and run on another $15 \%$ SDS-PAGE gel to see if purification was successful.

\section{Analysis using mass spectrometry}

Purified proteins, unseparated protein mixtures and whole spores were then analyzed using matrix assisted laser desorption ionization (MALDI) time of flight mass spectrometry (1). 


\section{RESULTS}

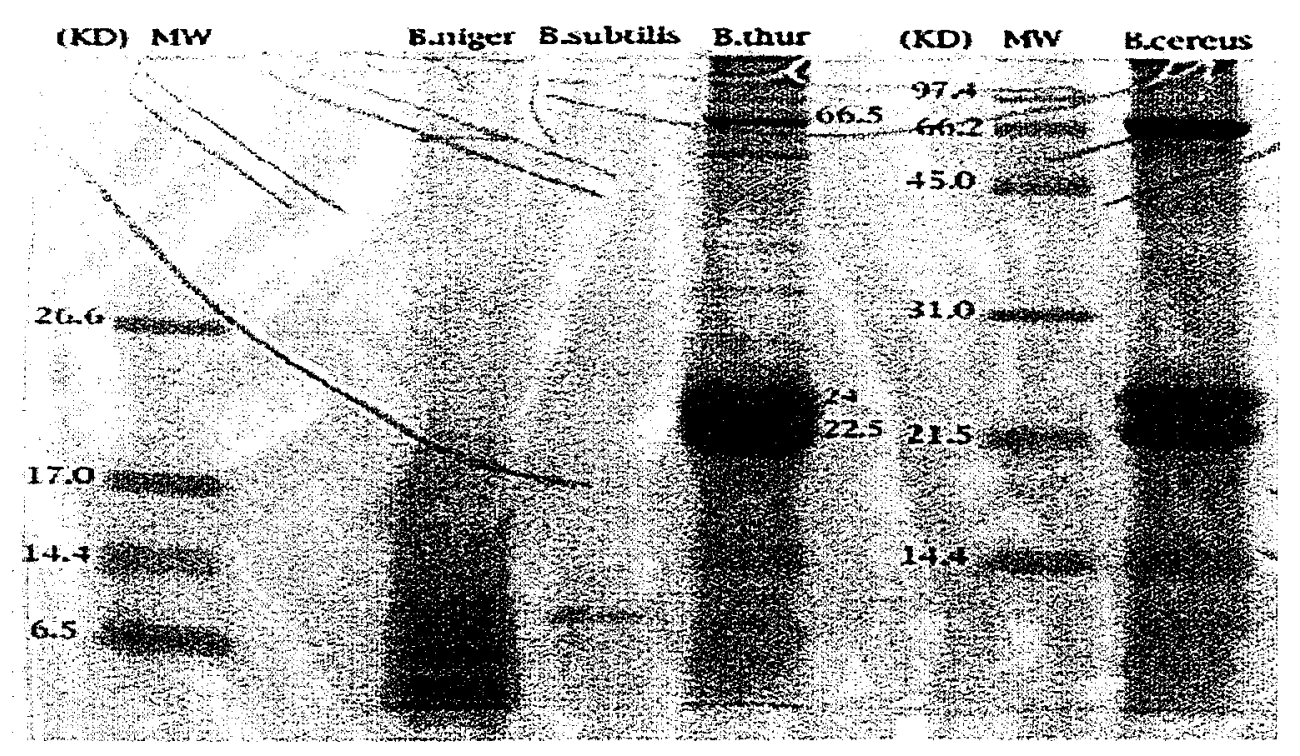

fig. 1. Crude extracts of Bacillus spore coat proteins extraction of whole spores on a 15\% SDS-PAGE gel.

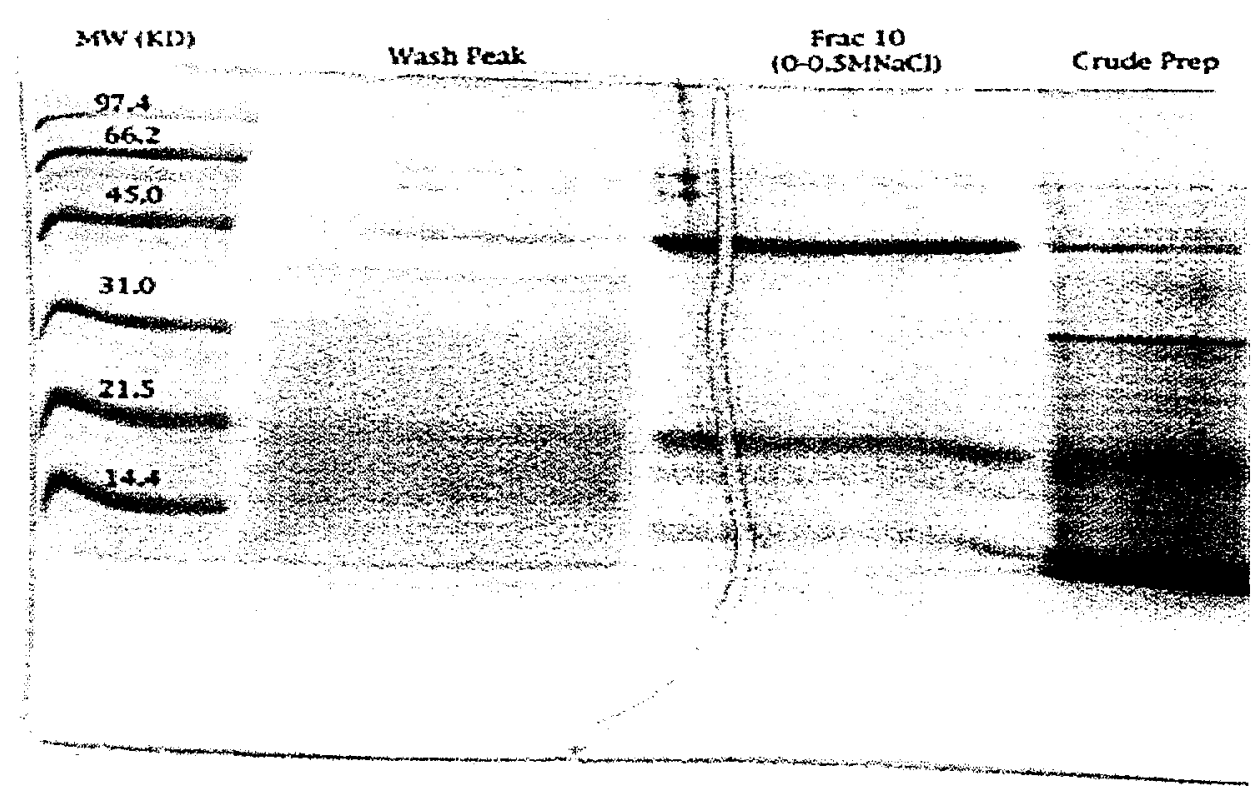

fig. 2. Ion exchange separation (SP sepharose, pH 7.5,(0-0.5M NaCl) of Bacillus subtilis spore coat proteins. 


\section{RESULTS}
B. thuringiensis
B. thuringiensis
MW
B. cereus
MW

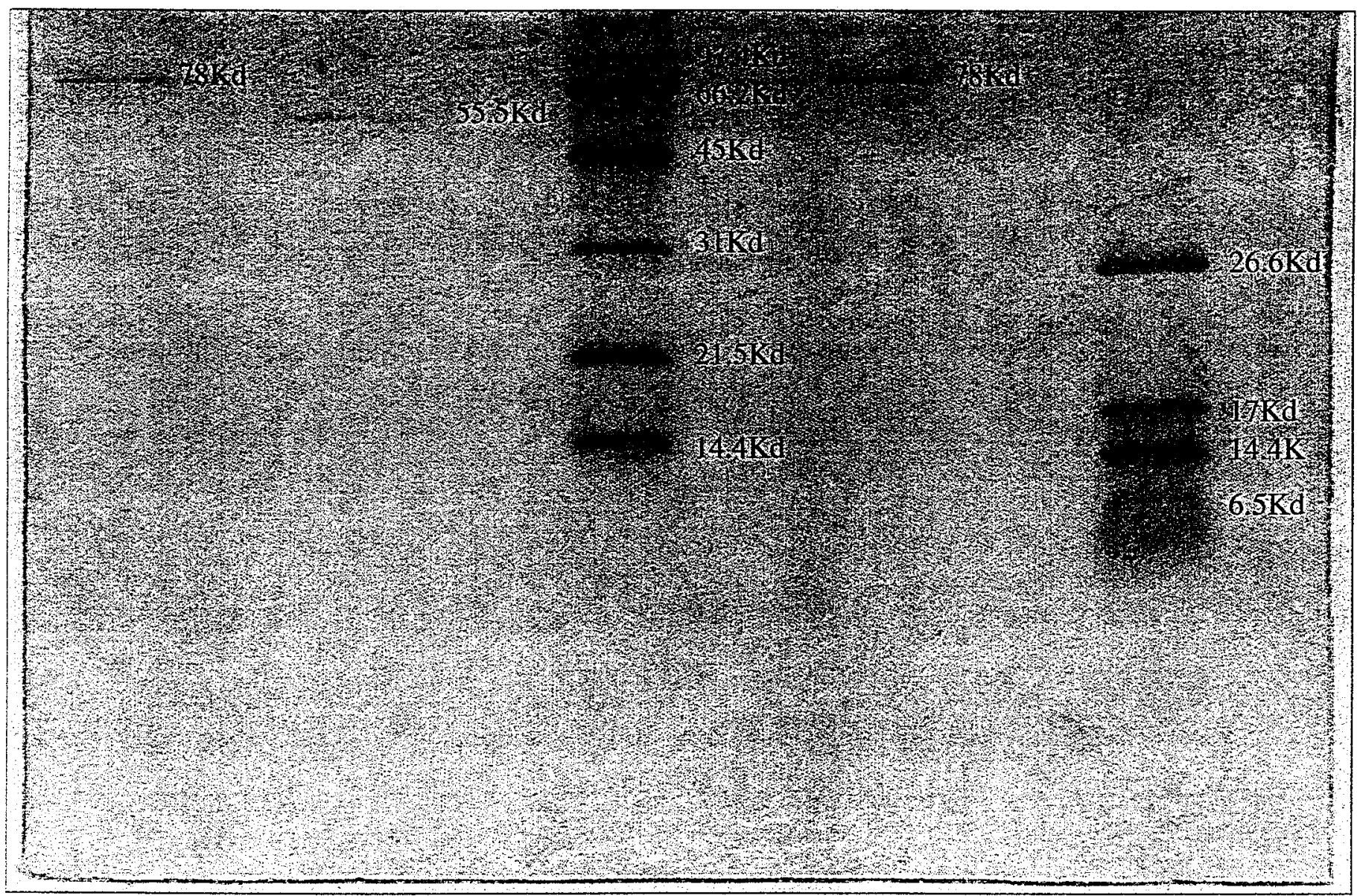

fig. 3. Gel electroeluted spore coat proteins of Bacillus cereus and Bacillus thuringiensis on a 15\% SDS-PAGE gel. 


\section{RESULTS}
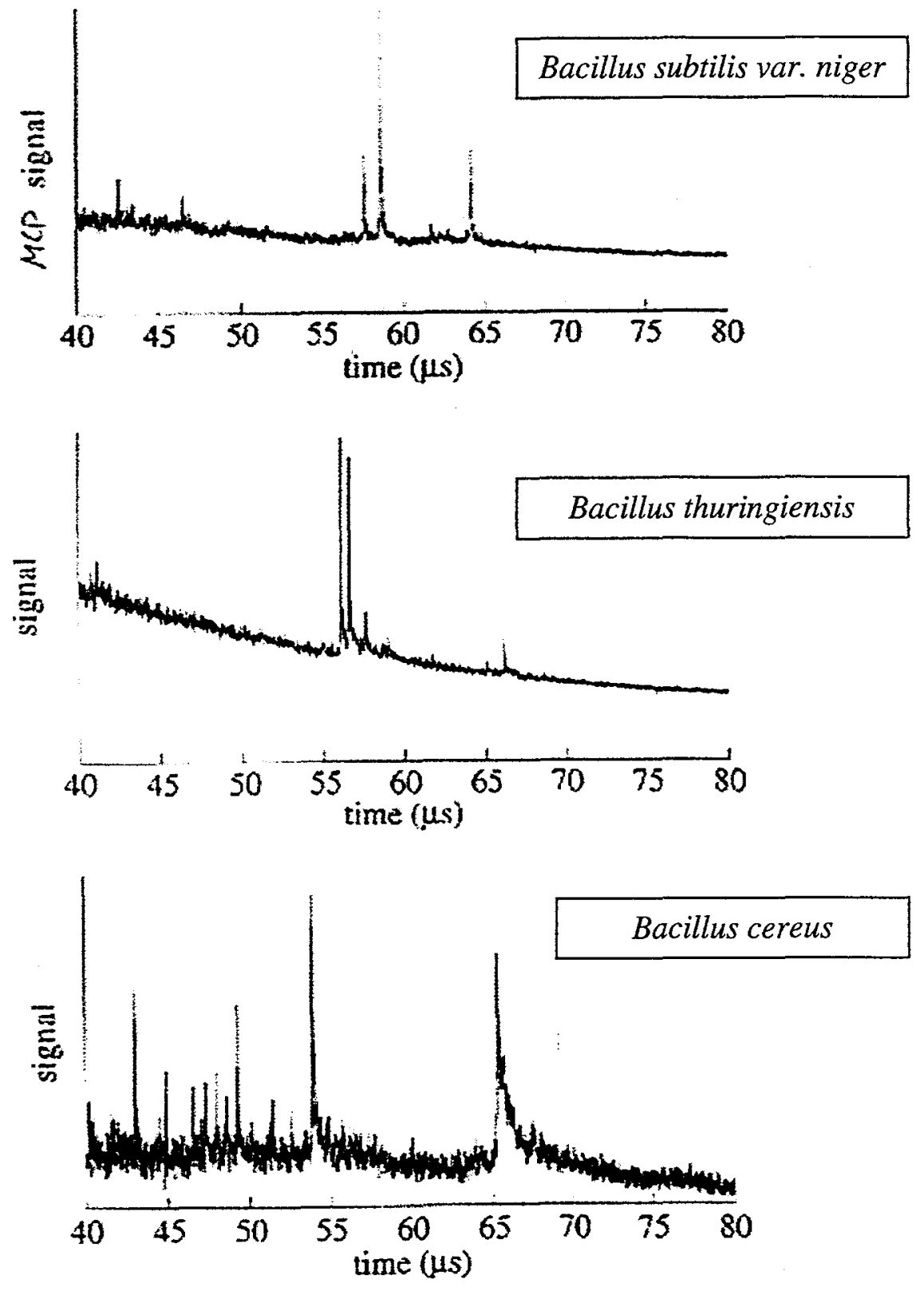

fig. 4. Signatures from MALDI - time of flight mass spectrometry analysis of three different Bacillus spore species. 


\section{DISCUSSION}

In the isolation step, lysozyme was added to remove (by lysis) vegetative cells, and dialysis was performed to remove low molecular weight solutes and exchange buffer. As can be seen from Fig. 1, visualization and molecular weight analysis of the major coat proteins of the analogs was achieved. The analogs chosen were used because they are all phylogenetically related to Bacillus anthracis. Bacillus cereus and Bacillus thuringiensis are actually so close to Bacillus anthracis that they are theorized to be variants of the same species (12). A single ion-exchange purification resulted in the separation of four of the coat proteins of Bacillus subtilis (Fig. 2). Further work is being done to improve this purification. Also, some of the major coat proteins of B. cereus and B. thuringiensis were successfully purified using electroelution techniques (Fig. 3) In the elution procedure, the gels were stained using copper stains instead of Coomassie blue. This is because Coomassie blue fixes the proteins in the gel and prevents elution whereas copper stained gels can be destained and the proteins eluted with ease.

The analysis of the whole spores was performed to observe any similarities or differences in signature between the species. Fig. 4 clearly indicates that each species has its own unique signature. Purified proteins and crude preps. are currently under analysis. It is anticipated that the mass spectrometry (MS) data obtained from their analysis will correlate with that of the spores. Also, the peaks in the MS signatures will be compared to the bands on the gels to see if the molecular weights of the proteins match. This will contribute to validating or discrediting the accuracy of the MS data. Currently, the mass spectrometer being used for analysis is a MALDI-time of flight mass spectrometer. However, in the proposed technique the mass spectrometer to be developed will be much more compact. MALDI is just being used to obtain preliminary data.

\section{CONCLUSION}

The differences observed in the MS signatures of the Bacillus spp spores demonstrates that MS is a promising tool for identifying bacteria. Current efforts are being geared towards developing the desired MS technique, purifying coat proteins, $\mathrm{N}$-terminal analysis of the proteins and simulated weaponization of the analogs. The project is on schedule and will be completed in the near future. 


\section{REFFERENCES}

1) Langry, Kevin et al. 1999. "Feasibility Investigations on the Real-time Detection and Identification of Biological Aerosols with Mass Spectrometry (New Proposal FY 99)."

2) Langry, Kevin and Joanne Horn. 1998. "Chemilumniscence Assay for the detection of Biological Warfare agents."

3) Atlas, R. M.. 1995. "Principles of Microbiology." Mosby-Year Book Inc.. $113-114$.

4) Atlas, R.M.. 1995. "Principles of Microbiology." Mosby-Year Book Inc.. 506.

5) Lazzarini, Robert A. and E. Santangelo. 1967. “Medium-dependent Alteration of Lysine Transfer Ribonucleic Acid in Sporulating Bacillus subtilis Cells." Journal of bacteriol. 94: 125-130.

6) Clark, George. (ed). "Staining procedures." $4^{\text {th }}$ edition. Williams and Wilkins. 390.

7) Jenkinson, H.F., W.D. Sawyer, and J. Mandelstam. 1981. "Synthesis and Order of Assembly for Spore Coat Proteins in Bacillus subtilis." Journal of General Microbiology. 123: 1-6.

8) Boyer, Rodney F.. 1993. "Modern Experimental Biochemistry." $2^{\text {nd }}$ edition. The Benjamin/Cummings publishing Co., Inc. 75-81.

9) Andrews, A. T.. 1987. "Electrophoresis - Theory, Techniques, and Biochemical and Clinical Applications." $2^{\text {nd }}$ edition. Clarendon Press, Oxford. 15-25.

10) Lehninger, Albert L., David L. Nelson, and Michael M. Cox. 1993. "Principles of Biochemistry." $2^{\text {nd }}$ edition. Worth Publishers, NY. 141-143.

11) Jacobs, E. and A. Clad. 1986. "Electroelution of fixed and stained membrane proteins from preparative SDS-polyacrylamide gels into membrane trap." Anal. Biochemistry. 154: 583-589.

12) http://www.eap.mcgill.ca/MagRack/JPR/JPR_22.htm 


\title{
Development of a Functional Chip for High-Throughput Screening of Protein-DNA Interactions.
}

\author{
Oliver Weiss', Ian McConnell', and Joanna Albala ${ }^{2}$. \\ ${ }^{1}$ University of the Pacific, Stockton, CA, 95211: ${ }^{2}$ Biology \\ and Biotechnology Research Program, Lawrence Livermore \\ National Labs, Livermore, CA, 94551.
}

\begin{abstract}
An oligonucleotide "functional chip" containing a variety of structurally different DNA fragments chemically linked to a glass surface is under development for analysis of protein-DNA binding interactions. The functional chip ultimately will be used to screen proteins for their ability to bind a wide range of DNA including single-stranded, double-stranded, and structurally-modified DNA fragments. Of special interest are novel DNA repair proteins which will be tested for their DNA binding capacity against these different DNA substrates. The prototype functional chip was generated by the application of DNA chemically cross-linked onto a glass slide in a microarray format. DNA spotted in this manner allows for analysis of proteins against different DNA samples on a single slide. The proteins to be investigated are applied individually to the chip and the protein-DNA interaction chemically stabilized. The protein-DNA interaction is visualized using fluorescent immunocytochemical techniques for detection of the protein-DNA binding events. To date, we have examined the protein-DNA interactions of RecA, a DNA-dependent ATPase. This work was performed under the auspices of the U.S. DOE by LLNL under contract no. W-7405-ENG48.
\end{abstract}




\section{INTRODUCTION}

The Human Genome Project has produced a tremendous amount of information about the sequence of the estimated one hundred thousand human genes. Now emphasis is being placed on determining the function of the newly identified genes, which must ultimately be examined at the protein level. Thus, the field of proteomics has emerged to study the protein complement of the human genome.

One of the most critical component of cellular biochemistry is the integrity of interaction between proteins and DNA. Protein-nucleic acid interactions are essential for the structural organization, replication, repair and expression of genetic information. Understanding the complexities of protein-DNA interactions is a fundamental step towards comprehending key aspects of disease biochemistry. The complexity of these cellular processes generally makes it necessary to analyze these interactions in vitro. Many techniques have been designed to offer insight into these processes which include filter binding studies, electrophoretic mobility shift assays and footprinting technologies.

The need has arisen for development of high-throughput proteomic strategies to analyze the function of these genes. Through the Undergraduate Research Semester program at Lawrence Livermore National Laboratory, a prototype functional chip containing various DNA fragments chemically linked to a glass surface has been developed for analysis of protein-DNA interactions in a high-throughput format. The use of a glass slide as a substrate facilitates the analysis of gene products and allows for study to be achieved cheaply and effectively.

RecA is a DNA-dependent ATPase that functions in homologous recombination, strand exchange, chromosome pairing, and DNA repair (Roca and Cox, 1997). This enzyme was selected for our initial study because it is known to bind both single-stranded and double-stranded DNA (Pugh and Cox, 1988; Bianco et al., 1998).

\section{METHODS}

\section{Attachment of DNA to Slides:}

Microscope slides were prepared for attachment of oligonucleotides using a modified protocol of Guo et al., 1994. Slides 
were then activated with the addition of a linker molecule to allow binding of the DNA to the glass surface (unpublished protocol courtesy of A.J. Wyrobek, LLNL). Specially designed oligonucleotides were synthesized and PAGE-purified using standard phosphoramidite chemistry (Operon Technologies Inc.; Alameda, CA). The oligonucleotides were applied to the slide in a microarray format using a Newport spotter (Norgren Systems; Palo Alto, CA) at 25 $\mathrm{pmol} / \mu \mathrm{l}$ in $\mathrm{NaCO}_{3}$ buffer, $\mathrm{pH}$ 8. Subsequently, slides were blocked with $1 \%$ ammonium hydroxide solution for 30 minutes to prevent non-specific binding.

\section{Binding of RecA to DNA:}

Using a slide with oligonucleotides attached, binding buffer (100 mM Tris pH 7.5, 0.6 M NaCl, $0.4 \mathrm{M} \mathrm{MgCl}_{2}, 1 \mathrm{mg} / \mathrm{ml} \mathrm{BSA}, 1 \mathrm{M}$ DTT) was applied for 15 minutes to prepare the slide for protein binding. RecA (New England Biolabs; Beverly, MA) was applied to the slide and incubated in the presence of ATP or ATP- $\gamma-S$ in binding buffer $\left(100 \mathrm{mM}\right.$ Tris $\mathrm{pH} 7.5,0.6 \mathrm{M} \mathrm{NaCl}, 0.4 \mathrm{M} \mathrm{MgCl}_{2}, 1$ $\mathrm{mg} / \mathrm{ml}$ BSA, $1 \mathrm{M}$ DTT, $100 \mu \mathrm{M} / \mathrm{ml}$ ATP/ATP- $\gamma-\mathrm{S}$ ) for 15 minutes. Unbound $\operatorname{Rec} A$ was removed by two washes in binding buffer. Application of $3 \%$ glutaraldehyde in TBS $(50 \mathrm{mM}$ Tris, $150 \mathrm{mM}$ $\mathrm{NaCl}$ ) was used to stabilize the protein-DNA interaction, and excess glutaraldehyde was immediately removed with TBS. Swine antiserum (Dako; Carpinteria, CA; 1:30 dilution in TBS) was applied for 30 minutes and washed with TBS. RecA antibody (Medical \& Biological Laboratories; Nagoya, Japan; 1:500 dilution in TBS) was applied to the slide and incubated overnight at $4^{\circ} \mathrm{C}$. Excess RecA antibody was removed by washing and a fluoroscein isothiocyanate (FITC)-conjugated secondary antibody (Boehringer Mannheim; Indianapolis, IN) was applied for 1 hour. Unbound secondary antibody was removed by washing with TBS and Vectorshield (Vector; Burlingame, CA) was applied to prevent quenching of the fluorescent signal. Results were analyzed using an UV microarray reader (Norgren Systems; Palo Alto, CA) with a FITC filter set. Images were captured using Image Workstation software version 0.01 (Norgren Systems; Palo Alto, CA). 


\section{RESULTS}

RecA is a DNA-dependent ATPase which first binds to DNA and then hydrolyzes ATP. The interaction of the RecA protein and DNA is instantaneous. In order to capture the protein-DNA interaction, a non-hydrolyzable from of ATP, ATP- $\gamma-S$, was used in the binding buffer to allow for the stable interaction of RecA with the DNA without the dissociatation of the enzyme from the DNA (Lee and Cox,1990). RecA in the presence of ATP- $\gamma-S$ showed a strong signal demonstrating that the enzyme is bound to the DNA and can be detected using the RecA antibody (Figure 1). RecA bound both single-stranded and double-stranded oligonucleotides. RecA in the presence of ATP however shows no fluorescent signal since RecA in the presence of ATP binds and dissociates quickly from the DNA and therefore is no longer bound nor detected by the antibody (Figure 2). This experiment demonstrates that it is possible to visualize a protein-DNA binding event in a microarray format on the functional chip. In addition, the lack of signal with ATP demonstates that the stabilizing agent, glutaraldehyde, did not create any erroneous interaction of the protein with the DNA.

Figure 1:

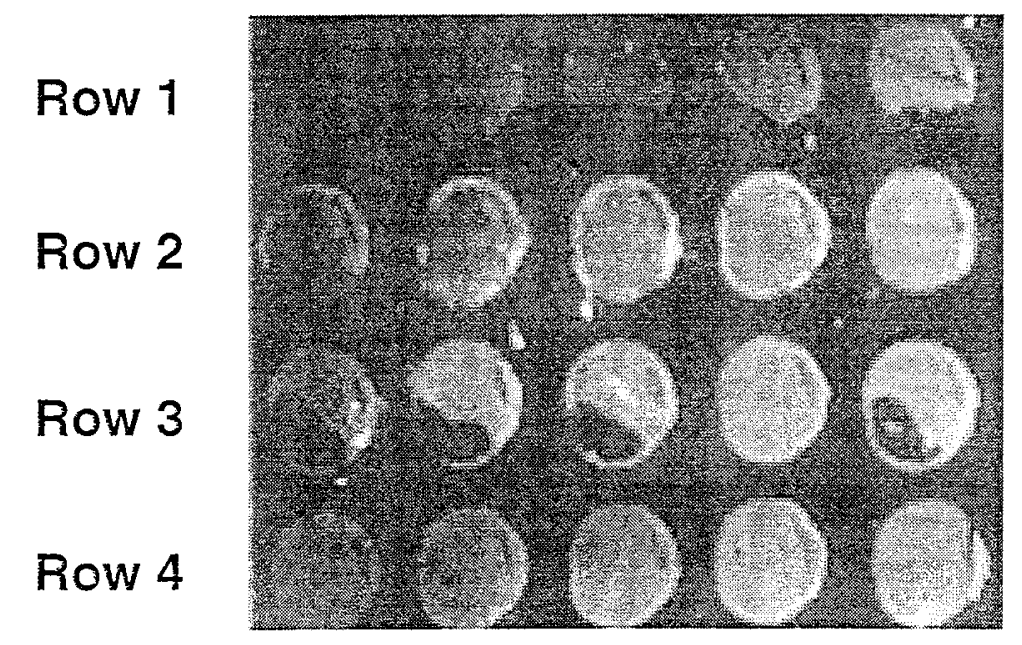

RecA in Presence of ATP- $\gamma-S$. Oligonucleotides were spotted onto a glass slide using robotic technology. Row 1 contains single-stranded oligonucleotides. Rows 2-4 
contain double-stranded oligonucleotides. Slides prepared with oligonucleotides were incubated with RecA and buffer containing ATP- $\gamma-S$. Application of RecA-specific antibody and FITC-labeled secondary antibody resulted in green fluorescent signals denoting protein-DNA interaction.

\section{Figure2:}

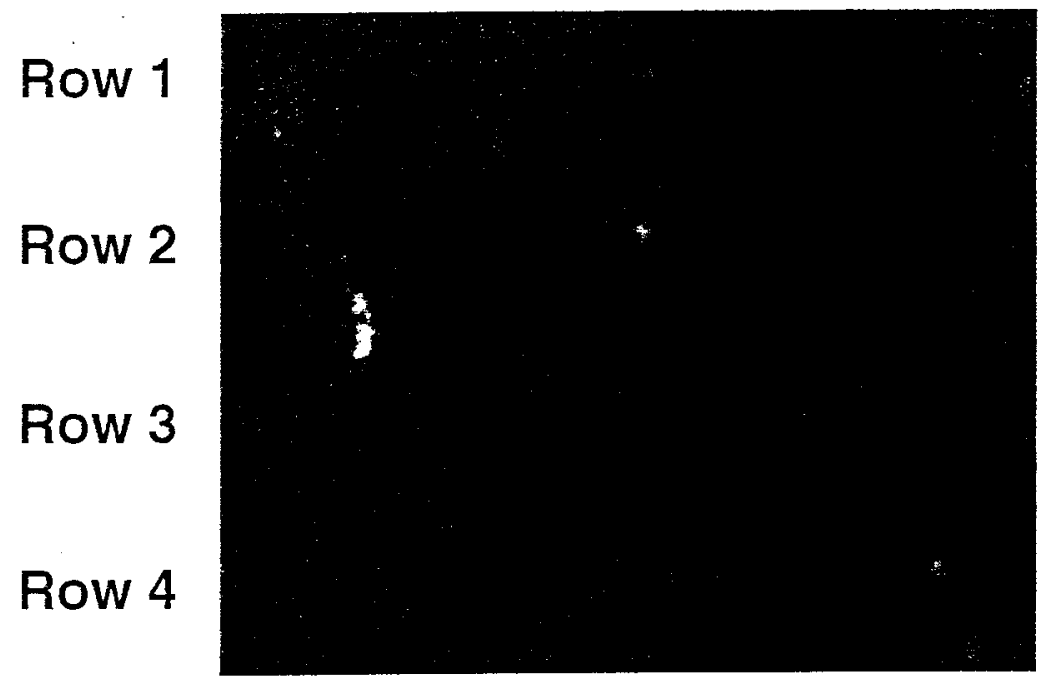

RecA in Presence of ATP. Oligonucleotides were spotted onto a glass slide using robotic technology. Row 1 contains single-stranded oligonucleotides. Rows 2-4 contain double-stranded oligonucleotides. Slides prepared with oligonucleotides were incubated with RecA and buffer containing ATP. Application of RecAspecific antibody and FITC-labeled secondary antibody showed no fluorescent signal denoting a lack of captured protein-DNA interaction. 


\section{DISCUSSION:}

Current methods to analyze gene expression primarily utilize either of two technologies. The oligonucleotide chip, pioneered by Fodor and co-workers and Affymetrix, Inc., consists of greater than 64,000 oligonucleotides attached in situ to a glass support (Fodor et al., 1991; Affymetrix, Inc; Santa Clara, CA). The oligonucleotide chip has been used primarily to identify specific mutations in a given gene by hybridization against a fluorescently-labeled substrate. The second method is the microarray, whereby DNA targets are systematically arranged on a glass slide and then hybridized with fluorescently-labeled complex targets for gene expression analysis (Jordan, 1998). By this technique, a large amount of information can be obtained examining global differences in gene expression among different cell populations, disease states and following drug treatments or toxic insult to whole cells. However, these technologies have yet to be extended beyond the examination of DNA/RNA molecules to dissect gene function.

The RecA experiment showed that it is possible to visualize a protein-DNA binding event in a microarray format. The demonstration of a RecA-DNA binding event on the functional chip is in agreement with other studies that have demonstrated the binding of RecA to both single-stranded and double-stranded DNA by more traditional means. Thus, the utility of a functional chip to identify protein-DNA binding events has been realized. Moreover, the application of the functional chip to identify novel DNA binding proteins will provide a high-throughput, effective way to begin to characterize those proteins involved in the complex processes of DNA replication, transcription, and repair and begin to elucidate many of the still unknown members of the human proteome. 


\section{REFERENCES}

Bianco, P., Tracy, R. B., and Kowalczykowski, S. C. (1998) DNA strand exchange proteins: A biochemical and physical comparison. Frontiers in Bioscience 3, 570-603.

Fodor, S. P., Read, J. L., Pirrung, M. C., Stryer, L., Lu, A. T., and Solas, D. (1991) Light-directed, spatially addressable parallel chemical synthesis. Science 251: 767-773.

Guo, Z., et al (1994) Direct fluorescence analysis of genetic polymorhpisms by hybridization with oligonucleotide arrays on glass supports. Nucleic Acid Res. 22, 5456-5465.

Jordan, B. R. (1998) Large-scale expression measurement by hybridization methods: From high-density membranes to "DNA chips". J. Biochem. 124: 251-8.

Lee, J.W. and Cox M.M. (1990) Inhibition of recA protein promoted ATP hydrolysis. 1. ATP gamma $\mathrm{S}$ and ADP are antagonistic inhibitors. Biochemistry. 33, 7666-76.

Pugh, B. F., and Cox, M. M. (1988) General mechanism for RecA protein binding to duplex DNA. J. Mol. Biol. 203, 479-93.

Roca, A.I. and Cox, M. M. (1997) RecA Protein: Structure, Function, and Role in Recombinational DNA Repair. Progress in Nuc. Acid Res. And Mol. Biology 56, 129-223. 